\title{
Foraminiferal and calcareous nannoplankton biostratigraphy of the upper Badenian-lower Sarmatian strata in the SE Polish Carpathian Foredeep
}

\author{
Danuta PERYT ${ }^{1, *}$, Małgorzata GARECKA ${ }^{2}$ and Tadeusz Marek PERYT ${ }^{3}$ \\ 1 Polish Academy of Sciences, Institute of Paleobiology, Twarda 51/55, 00-818 Warszawa, Poland \\ 2 Polish Geological Institute - National Research Institute, Carpathian Branch, Skrzatów 1, 31-560 Kraków, Poland \\ 3 Polish Geological Institute - National Research Institute, Rakowiecka 4, 00-975 Warszawa, Poland
}

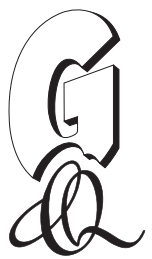

Peryt, D., Garecka, M., Peryt, T.M., 2021. Foraminiferal and calcareous nannoplankton biostratigraphy of the upper Badenian-lower Sarmatian strata in the SE Polish Carpathian Foredeep. Geological Quarterly, 65: 18, doi: 10.7306/gq.1584

Associate Editor: Michael A. Kaminski

The Badenian/Sarmatian boundary in the Central Paratethys has been traditionally identified by the faunal turnover recording an important environmental change possibly controlled by the change from marine to brackish conditions. The strata below the Badenian/Sarmatian boundary in the northern Carpathian Foredeep are included into the Pecten beds, and those above it into the Syndesmya beds. Foraminiferal study of the Babczyn 2 borehole which is one of the crucial sections in the northern Carpathian Foredeep, well-known for the depositional age of rhyolite tuff within the Pecten beds dated by Śliwiński et al. (2012) at $13.06 \pm 0.11 \mathrm{Ma}$, indicated that in fact the boundary occurs within the Syndesmya beds. This conclusion is based upon the rapid change from a stenohaline foraminiferal fauna to a euryhaline one, and the appearance of the species Anomalinoides dividens, the taxon regarded as the marker for the Sarmatian. In the Babczyn 2 and Cieszanów 1 (located $\sim 2.5 \mathrm{~km}$ basinward of Babczyn 2) boreholes, Anomalinoides dividens appears 3.1-3.8 $\mathrm{m}$ above the replacement of stenohaline by euryhaline foraminifers. The calcareous nannoplankton study shows that the upper Badenian and the lower Sarmatian strata in the studied sections represent the NN6, undivided NN6-NN7, and NN7 zones.

Key words: Middle Miocene, Carpathian Foredeep Basin, foraminifers, nannofossils, palaeoenvironments.

INTRODUCTION

The deposition of evaporites related to the Badenian Salinity Crisis in the Central Paratethys that started at 13.81 $\pm 0.08 \mathrm{Ma}$ (de Leeuw et al., 2010), was terminated when the Central Paratethys returned to open-marine conditions at 13.36 Ma (Simon et al., 2019) due to reconnection of the basin with the Mediterranean and Eastern Paratethys, primarily by tectonic modification of the interconnecting gateways (de Leeuw et al., 2018). In the Carpathian Foredeep and Foreland Basin - the largest Central Paratethyan basin - the marine shelf-slope facies have been replaced, during the late Serravalian and Tortonian, by shell-rich littoral and delta-front deposits and then by delta-top channel and floodplain facies that continued until the end of Messinian in the East Carpathian foreland (de Leeuw et al., 2020).

In the northern Carpathian Foredeep basin the strata above the Badenian evaporites are included into two regional stages:

* Corresponding author, e-mail: d.peryt@twarda.pan.pl Received: December 1, 2020; accepted: February 11, 2021; first published online: March 15, 2021
Badenian (upper part) and Sarmatian (e.g., Oszczypko et al., 2006; Kováč et al., 2017, with references therein). The boundary between those stages has been traditionally identified by the faunal turnover known as the Badenian-Sarmatian Extinction Event in the Central Paratethys (Harzhauser and Piller, 2007) recording an important environmental change possibly controlled by the change in seawater chemistry (in traditional approach - from marine to brackish conditions; Śliwiński et al., 2012, with references therein). A biostratigraphic zonation within the Badenian and Sarmatian of the northern Carpathian Foredeep was established based on the foraminifers (Łuczkowska, 1963, 1964, 1971; Odrzywolska-Bieńkowa, 1975; Czepiec, 1996; Garecka and Olszewska, 2011). In this region the taxon Anomalinoides dividens Łuczkowska defining the base of the Sarmatian, was first recognized and then considered as indicating the beginning of the Sarmatian in other Paratethyan basins (Filipescu, 2004; Tóth et al., 2010). The Sarmatian has been dated based on endemic assemblages (Filipescu et al., 2020).

The strata below the Badenian/Sarmatian boundary in the northern Carpathian Foredeep are included into the Pecten beds, and those above it into the Syndesmya beds (Fig. 1; Ney, 1969). The lithological transition between the beds is continuous although a hidden stratigraphical gap may exist (Krach, $1967,1981)$ that, as suggested by Śliwiński et al. (2012), is cor- 


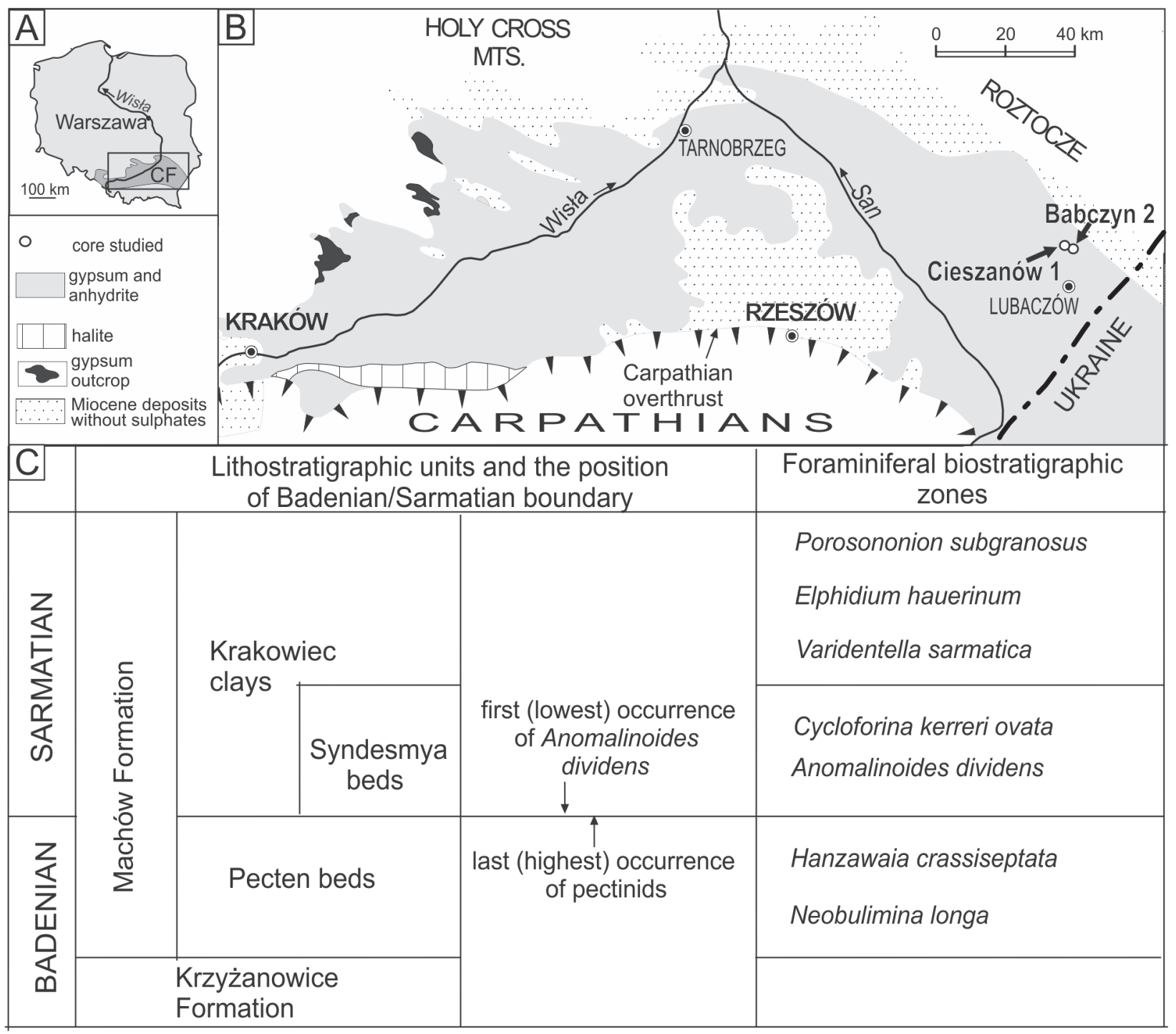

Fig. 1. Location and stratigraphical background

A - area of the Polish Carpathian Foredeep Basin (CF), quadrangle shows the area shown in B; B - distribution of Badenian sulphate deposits (after Kasprzyk, 2005 and Bukowski, 2011) and the location of Babczyn 2 and Cieszanów 1 boreholes; C - stratigraphy of Badenian-Sarmatian deposits in the northern Polish Carpathian Foredeep (modified figure 3 of Śliwiński et al., 2012)

related with deposits that contain several foraminiferal zones described by Kirchner (1956a, b) in more centre-basin locations. Thus the Pecten beds are stratigraphically condensed and thinned in relation to the foredeep interior. Śliwiński et al. (2012) dated a rhyolite tuff within the Pecten beds in the Babczyn 2 core in SE Poland (Fig. 1) that constrains its depositional age to $13.06 \pm 0.11 \mathrm{Ma}$. A younger age $(12.65 \mathrm{Ma})$ was determined for the supposed faunal turnover of the Badenian-Sarmatian Extinction Event that was triggered by a sudden change to brackish-marine conditions in the Central Paratethys (Simon et al., 2019). Śliwiński et al. (2012) concluded the that Badenian-Sarmatian Extinction Event is documented in the Babczyn 2 core by the disappearance of pectinids coincident with the topmost surface of the Pecten beds which grade upward into the Syndesmya beds that in turn lack typical fossils indicative of normal marine conditions. However, they did not have the opportunity to sample the Babczyn 2 core for biostratigraphic analysis. The aim of this paper is to fill this important gap through the study of two biostratigraphically important microfossil groups: foraminifers and calcareous nannoplankton.
As indicated by Filipescu et al. (2020), because of direct and indirect age indications, good resolution, and the relatively easy identification of reworked specimens, foraminifers seem to be the most reliable group for the biostratigraphic dating of the interval studied. Consequently, the Badenian/Sarmatian boundary in the Central Paratethys is clearly expressed by foraminiferal eco/bio-zones (Dumitriu et al., 2017: fig. 8, 2020). The use of calcareous nannoplankton has some limitations as late Badenian - Sarmatian stages comprise two nannozones NN6 and NN7, but they are commonly combined into one undivided NN6-NN7 Zone (e.g., Andreyeva-Grigorovich et al., 1997). According to Palcu et al. (2015) the interval identified as the Badenian/Sarmatian boundary transition is characterized by the relative abundance of $C$. pelagicus, which decreases significantly at the boundary, an increase in abundance of Reticulofenestra pseudoumbilicus, and a distinct drop in H. carteri (but see discussion in Silye and Filipescu, 2016). Gaździcka (2015) concluded that the appearance of Rhabdosphaera poculi Bóna and Kernerne and Rhabdosphaera procera Martini indicates the Sarmatian. 
In addition to study of the Babczyn 2 core (N50¹4'07.08", $\left.E 23^{\circ} 12^{\prime} 35.79^{\prime \prime}\right)$, we report the results of our examination of another core, Cieszanów 1 (N50¹4'01.33”, E23¹0'53.26”), located $\sim 2.5 \mathrm{~km}$ west (= basinward) of the Babczyn 2 borehole (Fig. 1). The two boreholes occur in the zone lying between the more central part of the Carpathian Foredeep that was the subject of several micropalaeontological studies (e.g., Odrzywolska-Bieńkowa, 1975; Czepiec, 1996, 1997; Czepiec and Kotarba, 1998; Garecka and Jugowiec, 1999; Olszewska, 1999; Garecka and Olszewska, 2011; Oszczypko-Clowes et al., 2012; Lelek et al., 2016), and the more marginal zone of the Middle Miocene basin in Roztocze (e.g., Łuczkowska, 1972; Odrzywolska-Bieńkowa, 1972a; Bielecka, 1974; Szczechura, 1982, 2000; Peryt, 1987) where the Badenian evaporites - the prime stratigraphical marker bed in the Carpathian Foredeep basin - are lacking.

\section{GEOLOGICAL SETTING}

The Carpathian Foredeep basin is one of the Central Paratethyan basins. It developed in front of the Carpathians in the Early Miocene and is subdivided in Poland into inner and outer parts (Ney et al., 1974). Marine Middle Miocene (Badenian and Sarmatian) deposits, which range in thickness from a few hundred metres in the northern-marginal part up to $3,000 \mathrm{~m}$ in the southeastern part of the Polish part of Carpathian Foredeep, form the bulk of the Foredeep basin fill (Ney et al., 1974).

The Badenian red-algal limestones and quartz arenites of the Pińczów Formation originated in shelf and near-shore environments and mudstones and clays in more basinal locations (e.g., Dziadzio et al., 2006). These are overlain by Badenian evaporites of the Krzyżanowice and Wieliczka formations (Alexandrowicz et al., 1982) deposited during the Badenian Salinity Crisis (Peryt, 2006, with references therein). In SE Poland, the sulphate deposits of the Krzyżanowice Formation consist of a sequence of lithofacies grouped into 18 lithostratigraphic units (from 'a' to 'r'; Kasprzyk, 1993) or seven lithosomes (from 'A' to 'G'; Kubica, 1992; Bąbel, 2005). In SE Poland, in the Lubaczów area (Fig. 2), the primary gypsum is partly or completely replaced by anhydrite and secondary gypsum (Kasprzyk, 1995). In the Cieszanów 1 borehole, units 'a'-'o' have a total thickness of $44.8 \mathrm{~m}$ (Kasprzyk, 1995), and in the Babczyn 2 borehole the gypsum sequence (32 m thick, depth 409-441 m) consists of units 'a'-l' and 'm'-'o' (Peryt and Kasprzyk, 1992). Unit 'o' contains an intercalation (2.3 m thick) of marly clays (depth: 413-415.3 m) rich in plant remains and carbonate lithoclasts (Pawłowska and Kubica, 1960) as well as crushed mollusc (Modiolus?) shell fragments (Śliwiński et al., 2012), and marine palynomorphs (dinoflagellate cysts) and foraminiferal assemblages indicating brackish to normal marine salinity at inner shelf depths (Peryt et al., 2020).

The Badenian evaporites are overlain by a sandy-silty series of the Machów Formation. Its upper Badenian part is referred to as the Pecten beds and the entire Sarmatian part is distinguished as the Krakowiec clays. In the lower part of the Krakowiec clays the Syndesmya beds occur (Jasionowski and Peryt, 2004, and Czapowski, 2004, with references therein; Fig. 1).

The Pecten beds are subdivided into two units (see Śliwiński et al., 2012, for detailed summary of the earlier research). The upper unit has a greater basinward extent, whereas the lower unit is commonly absent, especially toward the basin centre (Kowalewski, 1966). Basinwards, the Pecten beds grade into the supra-evaporite Spirialis clays (Śliwiński et al., 2012, with references therein). The sequence of the lower and upper units of the Pecten beds has been interpreted either as indicative of deepening (e.g., Kowalewski, 1957; Krach, 1962) or shallowing (Sulimski, 1956). Two of the regional benthic foraminiferal zones: the lower Neobulimina longa Zone and the upper Cibicides crassiseptatus (Hanzawaia crassiseptata) Zone occur in the Pecten beds (Odrzywolska-Bieńkowa, 1975); the latter of these is considered to be synchronous with the Velapertina (= Praeorbulina) indigena (Łuczkowska) planktonic foraminiferal zone (Cicha et al., 1998).

The Syndesmya beds in turn contain no pectinids and encompass the lowermost Sarmatian foraminiferal zones identified in the Carpathian Foredeep - the Anomalinoides dividens Zone and the Cycloforina karreri ovata Zone (Odrzywolska-Bieńkowa, 1975). The lithological transition between the Pecten beds and Syndesmya beds is continuous (Śliwiński et al., 2012). Śliwiński et al. (2012) confirmed the location of the Badenian/Sarmatian boundary between the Pecten beds and Syndesmya beds in the Babczyn 2 borehole as proposed by Pawłowska and Kubica (1960) at the highest occurrence of well preserved and identifiable pectinid shells, $6.0 \mathrm{~m}$ above the tuff found in the middle portion of the Pecten beds, $3.4 \mathrm{~m}$ above the gypsum. However, although some authors have suggested that the appearance of Anomalinoides dividens Łuczkowska coincides with the boundary between the Pecten beds and Syndesmya beds (i.e., between the Badenian and Sarmatian), others place the Badenian/Sarmatian boundary higher in the section, within the Syndesmya beds (e.g., Czapowski, 1994; see discussion in Śliwiński et al., 2012).

\section{MATERIAL AND METHODS}

We sampled the upper Badenian strata occurring above the Badenian evaporites and then the 32 and $18 \mathrm{~m}$ thick sequence of lower Sarmatian deposits in the Babczyn 2 and Cieszanów 1 cores, respectively, which are located above the Badenian/ Sarmatian boundary. The boundary was placed by Pawłowska and Kubica $(1960,1961)$ at a depth of $401.4 \mathrm{~m}$ and $368.5 \mathrm{~m}$, respectively: in the Babczyn 2 borehole it coincides with the boundary between the rocks assigned by them to the Pecten beds and Syndesmya beds, and in the Cieszanów 1 borehole it was placed at the base of marly clays overlying the $35 \mathrm{~cm}$ thick unit of calcareous marls containing $0.5-1.0 \mathrm{~cm}$ thick sandstone intercalations which in turn are underlain by clayey marls with common shell fragment and whole Pecten and other bivalve shells. These marls are intercalated with $1-15 \mathrm{~cm}$ thick tuffites and rare sandstones (up to $20 \mathrm{~cm}$ thick) and marly limestone $(20 \mathrm{~cm})$.

A total of 88 samples from the Babczyn 2 and Cieszanów 1 borehole sections have been studied for foraminifers: 51 samples from the $40 \mathrm{~m}$ thick interval in the Babczyn 2 borehole and 37 samples from the $36 \mathrm{~m}$ thick interval in the Cieszanów 1 borehole sections. The sampling distance in the Babczyn 2 section was $\sim 1 \mathrm{~m}$ in the Pecten beds (samples 8-21), $0.5 \mathrm{~m}$ in the lowermost part of the Krakowiec clays (samples 22-29) and $\sim 1 \mathrm{~m}$ in the higher part of the studied interval of Krakowiec clays" (samples 32-59). Similarly, in the Cieszanów 1 borehole section the sampling distance was $\sim 1 \mathrm{~m}$ in the sampled interval except for the $8 \mathrm{~m}$ thick interval around the boundary between the Pecten beds and Krakowiec clays (samples 25-42) where it was $0.5 \mathrm{~m}$ (or less).

The same samples have been used for the nannoplankton study although their number, for the nannoplankton study, was reduced as usually, every second sample studied for foraminifers was examined. In total, 51 samples have been 


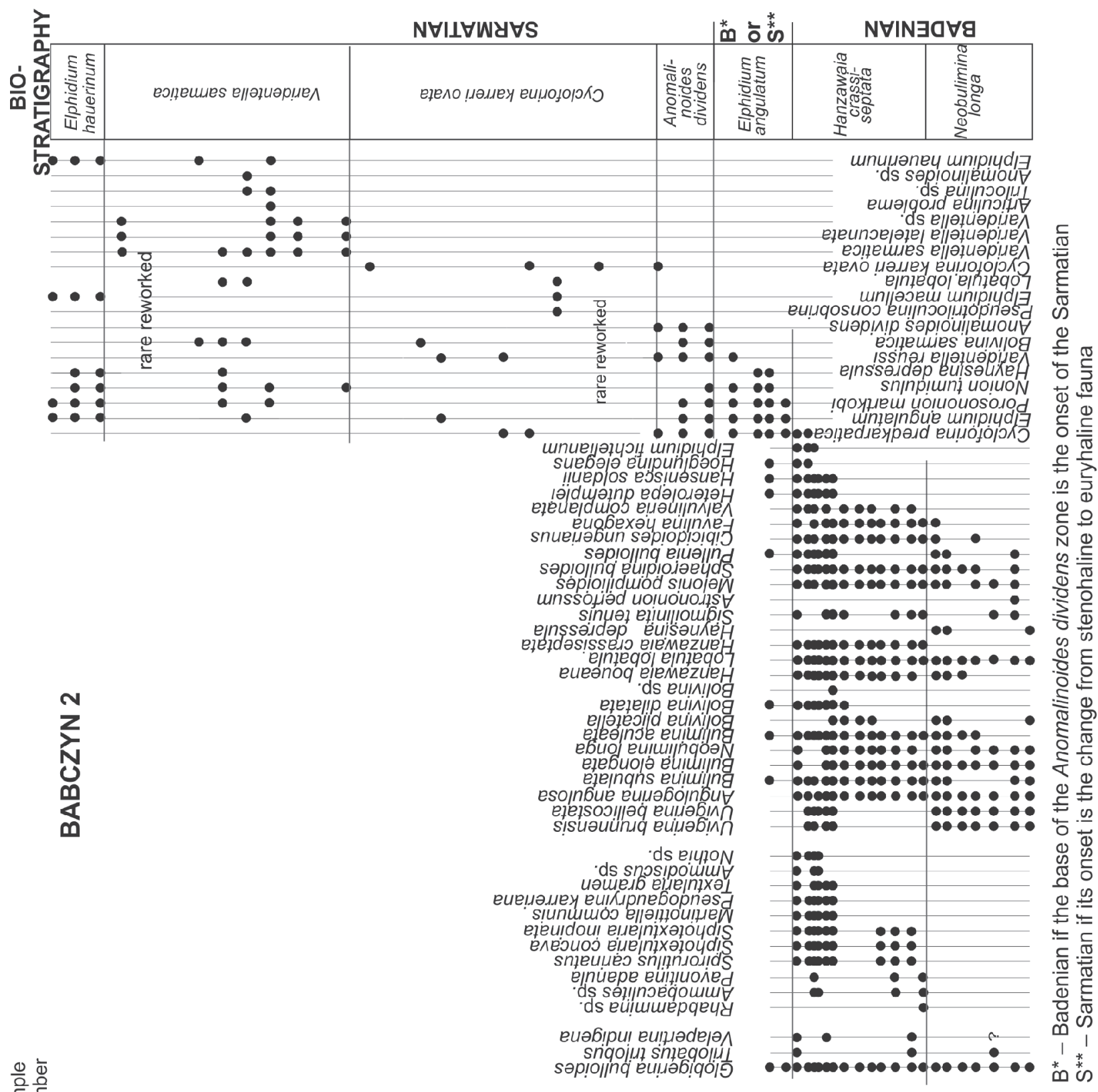

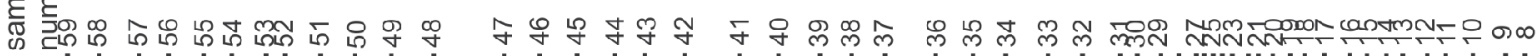

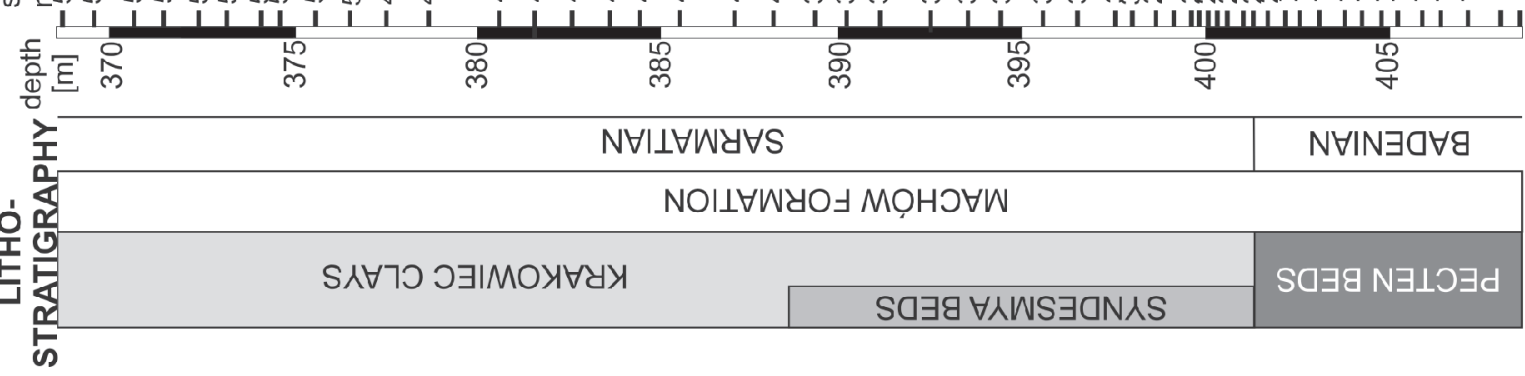


used for the nannoplankton study (27 samples from Babczyn 2 and 24 samples from Cieszanów 1).

Washed residues for foraminiferal study were obtained from the rocks by disaggregation using $\mathrm{Na}_{2} \mathrm{SO}_{4}$. The foraminiferal specimens from the $>63 \mu \mathrm{m}$ size fraction were picked for the biostratigraphic analyses. Presence-absence observations for the Babczyn 2 and Cieszanów 1 borehole sections are shown in Figures 2 and 3 . The most common species are illustrated in Figure 4. Foraminiferal biozones follow Łuczkowska (1964) and have been revised in this study. The figured specimens are deposited in the Institute of Paleobiology, Polish Academy of Sciences, Warszawa (ZPAL F. 75).

The smear slides for nannoplankton studies were prepared according to the method described by Báldi-Beke (1984). A fine water suspension of the rock, after stirring and short period of settling, was spread out on a microscopic glass slide. After drying, the microscope slide was covered with Canada balsam and a cover glass. The slides were inspected using a Nikon Eclipse LV100Pol at 1000x magnification. Photos were taken under the light microscope using a Nikon DS-Fi1 camera. The occurrence of calcareous nannoplankton taxa in particular samples is shown in Figures 5 and 6, and the taxa are shown in Figures 7 and 8 .

\section{RESULTS}

\section{FORAMINIFERS}

The studied successions contain well-preserved planktonic, calcareous benthic, and agglutinated foraminifers. More than 75 species representing the following genera: Articulina, Cycloforina, Pseudotriloculina, Pyrgo, Quinqueloculina, Sigmoilinita, Triloculina, Varidentella, Elphidium, Haynesina, Porosononion, Anomalinoides, Heterolepa, Hanzawaia, Lobatula, Cibicidoides, Elphidiella, Melonis, Nonion, Pullenia, Bolivina, Bulimina, Uvigerina, Angulogerina, Sphaeroidina, Favulina, Fissurina, Lagena, Lenticulina, Nodosaria, Globigerina, Velapertina, Trilobatus, Ammobaculites, Ammodiscus, Martinottiella, Siphotextularia, Textularia, Spirorutilus, Pavonitina, Pseudogaudryina, Rhabdammina, and Nothia were recorded in the studied intervals of the Babczyn 2 and Cieszanów 1 boreholes (Appendix 1*; Figs. 3 and 4).

$$
\begin{aligned}
& \text { BABCZYN } 2 \\
& (\text { FIG. 2) }
\end{aligned}
$$

In the lower part of the studied succession (depth 404.3-409.1 m), foraminiferal assemblages are characterized by an abundance of planktonic and calcareous benthic foraminifers; agglutinated ones are absent. The most abundant planktonic species is Globigerina bulloides. Among the calcareous benthic foraminifers elongated forms of Uvigerinidae (Uvigerina bellicostata, U. brunnensis, U. semiornata and Angulogerina angulosa) and subcylindrical Buliminidae (Bulimina elongata, B. insignis, B. aculeata, B. subulata) are dominant. Hanzawaia boueana, Lobatula lobatula, Bolivina plicatella, Bulimina elongata, Neobulimina longa, Pullenia bulloides, Sphaeroidina bulloides, Melonis pompilioides, and Cibicidoides ungerianus occur rarely in this part of the section.

The following, $4.9 \mathrm{~m}$ thick rock interval (399.4-404.3 $\mathrm{m}$ ) is characterized by abundant, highly diversified foraminiferal assemblages. Planktonic foraminifers are represented by
Globigerina bulloides, Velapertina indigena, and Trilobatus trilobus. Agglutinated benthic foraminifers, absent in the underlying interval, are an important component of this assemblage. The most common species are Siphotextularia concava, S. inopinata, Spirorutilus carinatus, Martinottiella communis, and Pseudogaudryina karreriana. In addition to agglutinated forms, benthic foraminiferal assemblages in this interval possess additional calcareous species. Species which characterize this part of the succession are: Hanzawaia crassiseptata, Valvulineria complanata, Cibicidoides ungerianus. Very common are Melonis pompilioides, Sphaeroidina bulloides, Hanzawaia boueana and Lobatula lobatula. In the upper part Pullenia bulloides, Heterolepa dutemplei and Hansenisca soldanii are important contributors to the assemblages. This abundant, highly diversified foraminiferal assemblage suddenly disappears at a depth of $399.4 \mathrm{~m}$ (sample 28).

The next, $3.8 \mathrm{~m}$ thick rock interval (395.6-399.4 m), yielded a very poor foraminiferal assemblage, taxonomically completely different from the older one, composed by small-sized Elphidium (E. angulatum), Porosononion martkobi, Nonion tumidulus) and hauerinids (Cycloforina predkarpatica, Varidentella reussi).

The following, $2.1 \mathrm{~m}$ thick rock interval (393.5-395.6 $\mathrm{m}$ ) is characterized by an almost monospecific assemblage of Anomalinoides dividens. Rare specimens of species characteristic for the assemblage from the underlying interval were also recorded.

The next, $12.9 \mathrm{~m}$ thick rock interval (380.6-393.5 m) yielded poor foraminiferal assemblages composed of a few hauerinid species: Cycloforina predkarpatica, Varidentella reussi, and C. karreri ovata. Rare reworked uppermost Badenian foraminifers occur, mainly in the lower part of this inerval.

The overlying, $10.2 \mathrm{~m}$ thick rock interval $(370.4-380.6 \mathrm{~m})$ is characterized by low diversity, sparse foraminiferal assemblages composed mainly by hauerinids. The most common genus is Varidentella (V. sarmatica, V. latelacunata); Articulina problema is also present there. Rare occurrences of Elphidium angulatum, Porosononion martkobi, and Nonion tumidulus are recorded mainly in the lower part of this interval. At a depth of $374.5-376.5 \mathrm{~m}$ Bolivina sarmatica is a significant component of the assemblages.

The uppermost, $2.0 \mathrm{~m}$ thick rock interval, (368.4-370.4 m) yielded low diversity foraminiferal assemblages dominated by Porosononion martkobi, Nonion tumidulus and elphidiids (E. hauerinum, E. angulatum). Psudotriloculina consobrina and Cycloforina predkarpatica are also present.

$$
\underset{\text { (FIG. 3) }}{\text { CIESZANóW }} 1
$$

The basal interval of the studied succession, $2.65 \mathrm{~m}$ thick (depth $383.25-385.9 \mathrm{~m}$ ), is characterized by an abundant occurrence of tiny, small-sized elphidiids like Elphidium angulatum, E. advenum, Elphidiella artifex, and nonionids Haynesina depressula, Nonion sp. They are accompanied by Ammonia sp., Pseudotriloculina consobrina, Quinqueloculina akneriana, Cycloforina gracilis, Bolivina plicatella, Fissurina marginata, Rosalina sp., and Favulina hexagona.

The following, $7.65 \mathrm{~m}$ thick rock interval (375.6-383.45 m) is characterized by higher diversity benthic foraminiferal assemblages. Several new species appear: abundant Bulimina elongata accompanied by less common Lobatula lobatula, Elphidium macellum, Sigmoilinita tenuis, Bolivina plicatella, 

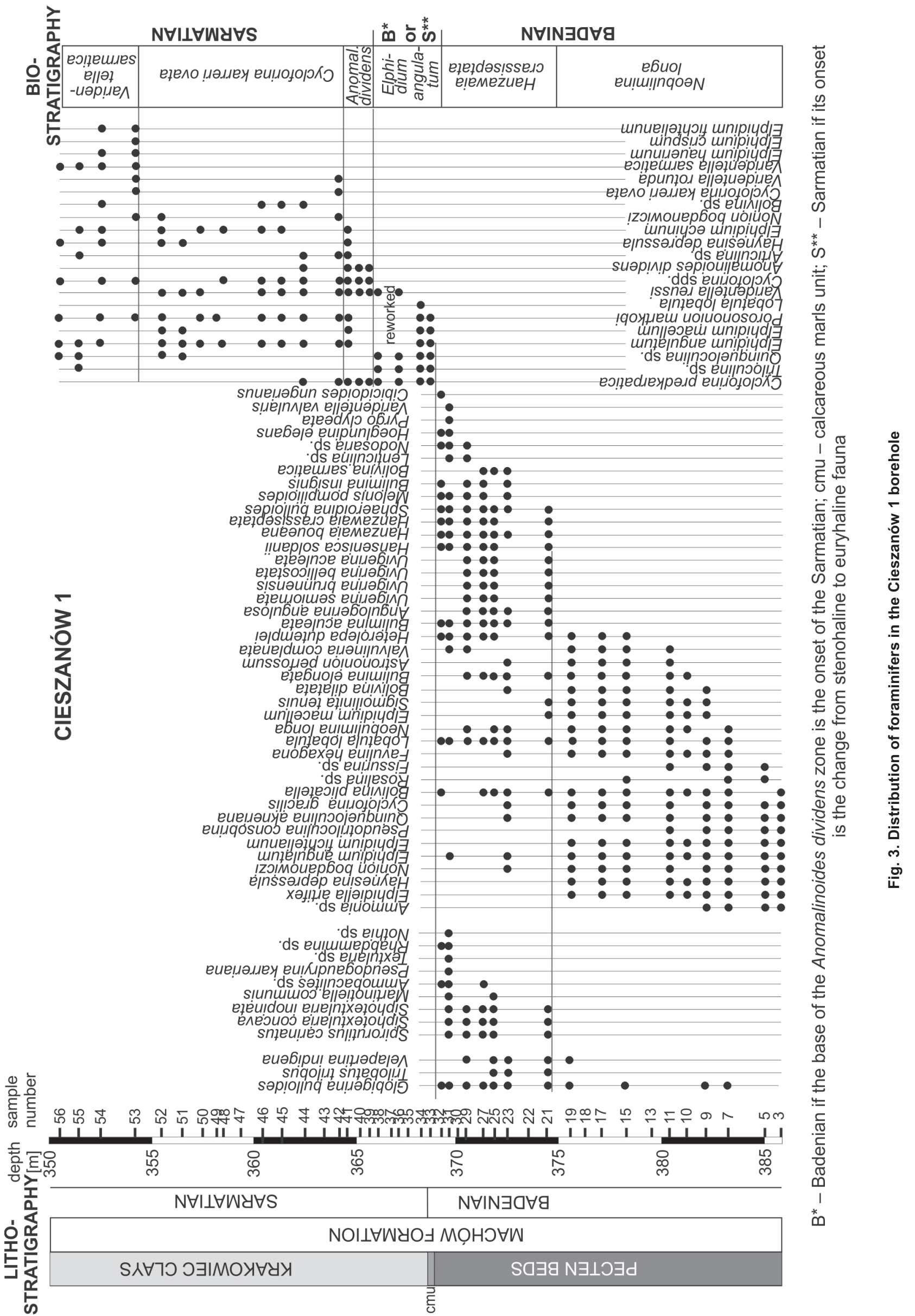

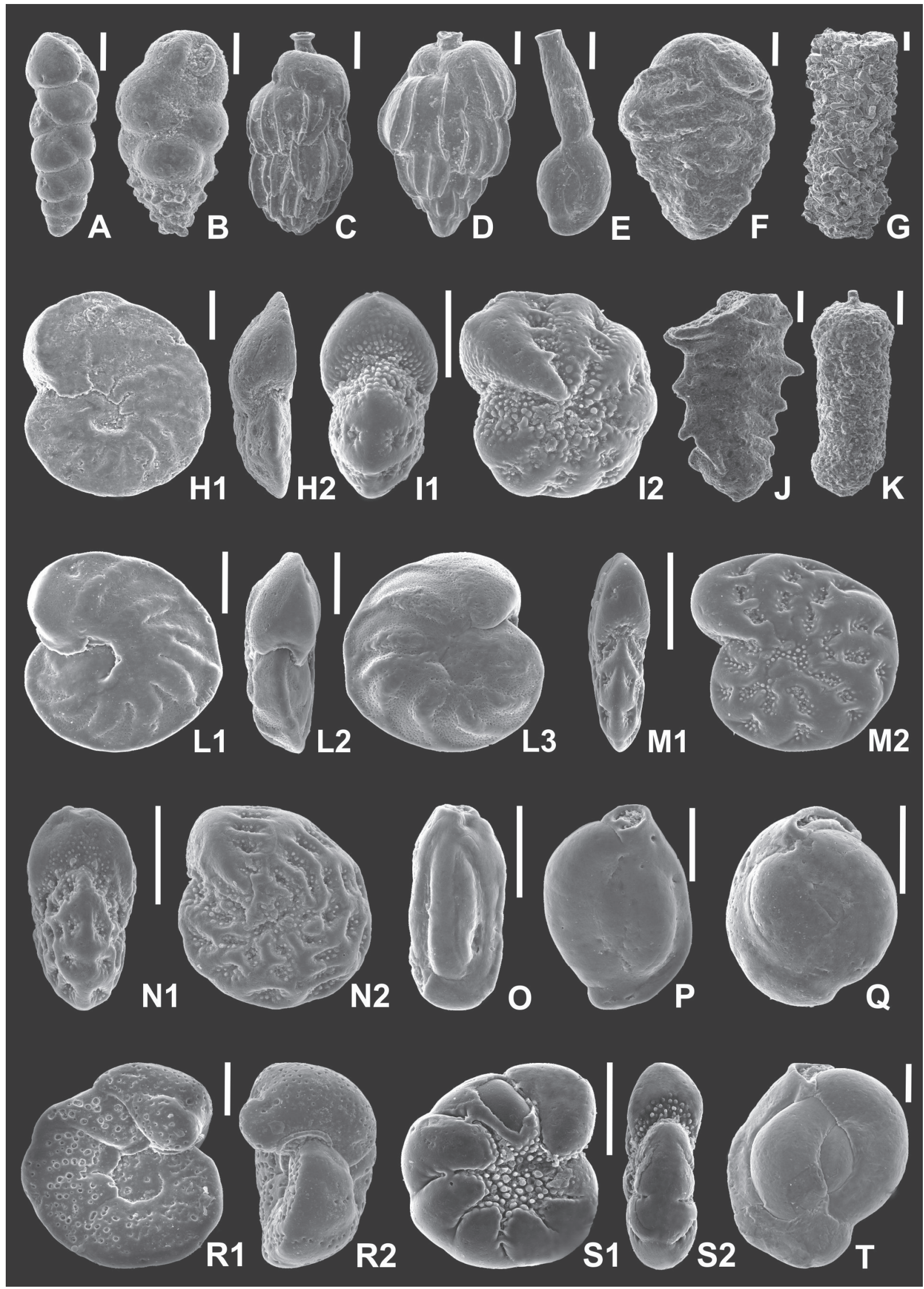

Fig. 4. Foraminifers from the Babczyn 2 (A, E, F, I-K, M, N, P-T) and Cieszanów 1 (B-D, G, H, L, O) boreholes

A - Neobulimina longa Venglinskyi, sample 17; B - Bulimina subulata Cushman \& Parker, sample 19; C - Uvigerina bellicostata Łuczkowska, sample 19; D - Uvigerina semiornata d'Orbigny, sample 19; E - Articulina problema Bogdanowicz, sample 48; F Siphotextularia inopinata Łuczkowska, sample 28; G - Rhabdammina sp., sample 31; H - Hanzawaia boueana (d'Orbigny), sample 19; I Elphidium angulatum (Egger), sample 29; $\mathbf{J}$ - Spirorutilus carinatus (d'Orbigny), sample 17; K - Martinottiella communis (d'Orbigny), sample 28; L - Hanzawaia crassiseptata (Łuczkowska), sample 32; M - Elphidium advenum limbatum (Chapman), sample 33; $\mathbf{N}$ - Elphidium hauerinum (d'Orbigny), sample 57; O -Cycloforina predkarpatica (Serova), sample 15; P - Quinqueloculina akneriana d'Orbigny, sample 32; $\mathbf{Q}$ - Varidentella reussi (Bogdanowicz), sample 47; $\mathbf{R}$ - Anomalinoides dividens Łuczkowska, sample 35; $\mathbf{S}$ - Porosononion martkobi (Bogdanowicz), sample 31; T - Varidentella sarmatica (Karrer), sample 49; scale bars - $100 \mu \mathrm{m}$ 
Astrononion perfossum, and Heterolepa dutemplei. In the lowermost part of this interval rare specimens of the planktonic species Globigerina bulloides are recorded.

The next, $6.75 \mathrm{~m}$ thick interval (368.85-375.6 m), yields a high diversity foraminiferal assemblage composed of both planktonic and benthic foraminifers. Planktonic forms dominate in the assemblages in this interval. The most abundant is Globigerina bulloides; and Velapertina indigena and Trilobatus trilobus are common.

Benthic foraminiferal assemblages are very different from the ones recorded in the underlying part of the section. They are composed of medium to large-sized calcareous and agglutinated species. The tiny, small-sized elphidiids and nonionids almost disappear. Several species not recorded in the lower part of the section are very common in this rock interval: Melonis pompilioides, Sphaeroidina bulloides, Hanzawaia boueana, H. crassiseptata, Hansenisca soldanii, Heterolepa dutemplei, Bulimina spp. and Uvigerina spp. Of the agglutinated forms the most common are Spirorutilus carinatus, Siphotextularia inopinata and S. concava.

Then, this highly diversified foraminiferal assemblage disappears and in the $3.1 \mathrm{~m}$ thick overlying strata (the depth interval $365.75-368.85 \mathrm{~m}$ ) is replaced by a completely new assemblage. Hauerinids (Cycloforina predkarpatica, Triloculina sp., Quinqueloculina sp.), Porosonion martkobi and Elphidium angulatum are the main components of the assemblage. At a depth of $366.8 \mathrm{~m}$ (sample no. 37) reworked foraminifers are recorded.

The $1.55 \mathrm{~m}$ thick interval that follows $(364.7-365.75 \mathrm{~m})$ is characterized by an almost monospecific foraminiferal assemblage of Anomalinoides dividens. Only rare hauerinids (Triloculina, Quinqueloculina, Cycloforina) and Elphidium are minor components.

The next interval (350.0-364.7 m) is characterized by common Varidentella sarmatica, Triloculina spp., non-keeled elphidiids, and rare Elphidium fichtelianum and E. crispum.

\section{CALCAREOUS NANNOPLANKTON}

Calcareous nannofossil assemblages in the analysed samples are moderately to poorly preserved. Twenty-nine species representing the following genera: Braarudosphaera, Calcidiscus, Calciosolenia, Coccolithus, Coronocyclus, Cyclicargolithus, Discoaster, Hayella, Helicosphaera, Holodiscolithus, Pontosphaera, Reticulofenestra, Sphenolithus and Umbilicosphaera were recorded in the studied intervals of the Babczyn 2 and Cieszanów 1 boreholes (Appendix 1; Figs. 5 and 6). The most abundant taxa are Coccolithus pelagicus and Reticulofenestra pseudoumbilicus. Helicosphaera carteri and H. spp. (small forms) occur more rarely than the two above-mentioned species. Reworked Mesozoic (mainly Upper Cretaceous) and Paleogene (mainly Eocene) taxa are present throughout the studied sections. Diagnostic for Middle Miocene nannofossil stratigraphy Sphenolithus and Discoaster species occur only sporadically (as individuals) in some samples (mainly Sphenolithus). Coccospheres are sporadically present in the investigated samples possibly because many of them have been disaggregated.

Besides the calcareous nannoplankton ascidian spicules, calcareous dinoflagellata, frustules of diatoms and Bolboforma spp. were found. Ascidians (sea squirts) are benthic tunicates (Young, 1998; Varol, 2006; Łukowiak et al., 2016). The spicules they produce occur in nannoplankton preparations, especially from shallow marine environments. They have been recorded from Jurassic to Recent and occur also in Middle Miocene sediments. They occur in almost all the samples. Bolboforma spe- cies (Protophyta group) are described from the Middle Miocene sediments of the Carpathian Foredeep (OdrzywolskaBieńkowa, 1976; Szczechura, 1997, 2000; Paruch-Kulczycka, 2003). These marine microfossils produced calcitic monocrystalline spheroidal tests with or without inner cysts and with various types of ornamentation. Due to the preservation state of observed fragments it was impossible to relate them to the specific species and/or Bolboforma zones. Thoracosphaera species are a common constituent of the marine nannoplankton (Inouye and Pienaar, 1983). They are placed in calcareous nannoplankton because of their size. These are dissolution resistant forms which occur abundantly in marine surface (oligotrophic and eutrophic) waters (Karwath et al., 2000; Gussone et al., 2010). An increasing abundance of these forms indicates, according to Agnini et al. (2007), stressed environmental conditions in the photic zone.

$$
\begin{aligned}
& \text { BABCZYN } 2 \\
& (\text { FIG. 5) }
\end{aligned}
$$

In sample 8 the calcareous nannoplankton assemblage consists of Reticulofenestra pseudoumbilicus, Coccolithus pelagicus, Helicosphaera carteri, Holodiscolithus macroporus, and common fragments of pyritized Bolboforma forms. Species such as: Braarudosphaera bigelowii, Cyclicargolithus floridanus, Pontosphaera multipora, Sphenolithus abies, Umbilicosphaera jafari, $U$. rotula and calcareous dinoflagellata occur rarely. Reworked single Cretaceous and Paleogene forms were identified.

The interval between samples 9 and $17(402.7-408.0 \mathrm{~m})$ is characterized by the occurrence of Calcidiscus macintyrei, C. leptoporus, C. pataecus, Sphenolithus abies and Umbilicosphaera rotula species. Helicosphaera walbersdorfensis, Holodiscolithus macroporus, Helicosphaera carteri, Sphenolithus moriformis and Thoracosphaera occur very rarely. Reworked Cretaceous and Paleogene forms, fragments of Bolboforma spp. and foraminifera tests were also found. In the interval of 406.5-402.7 m (samples 11 and 17) Reticulofenestra pseudoumbilicus prevails in terms of specimens over Coccolithus pelagicus and other species. Other common species in sample 17 include Calcidiscus macintyrtei and Sphenolithus abies.

A very impoverished calcareous nannoplankton assemblage with Reticulofenestra pseudoumbilicus, Coccolithus pelagicus, Bolboforma spp., single other forms and destroyed fragments of undistinguishable forms/elements was observed in sample 19 (depth of $402.9 \mathrm{~m}$ ). In sample 21 (depth of $401.9 \mathrm{~m}$ ) Reticulosphaera pseudoumbilicus is a dominant component of the assemblage. Coccolithus pelagicus, Cyclicargolithus floridanus, Helicosphaera carteri, Holodiscolithus macroporus, Sphenolithus moriformis, and Umbilicosphaera rotula are found as individual specimens. In samples 23,25 , and 27 (depth of $399.8-400.8 \mathrm{~m}$ ) the most common forms are Reticulofenestra pseudoumbilicus, C. pelagicus, Helicosphaera carteri and, in sample 23 only, S. moriformis. In sample 27 the occurrence of small Helicosphaera forms, $H$. walbersdorfensis, $H$. carteri, Holodiscolithus macroporus and Rhabdosphaera sp., Calciosolenia murrayi, coccospheres of Coccolithus pelagicus, and small forms of Braarudosphaera bigelowii was recorded. The other species (Appendix 1) from this interval occur very rarely. In samples 25 and $27 \mathrm{H}$. carteri occur more often than in samples from the lower part of the section. In sample 29 (depth of $398.8 \mathrm{~m}$ ) the nearly mass occurrence of $C$. pelagicus mainly small sized, and reworked Paleogene and Cretaceous forms were observed. Small, medium and large coccoliths of Coccolithus pelagicus were observed in sample 29. Small 


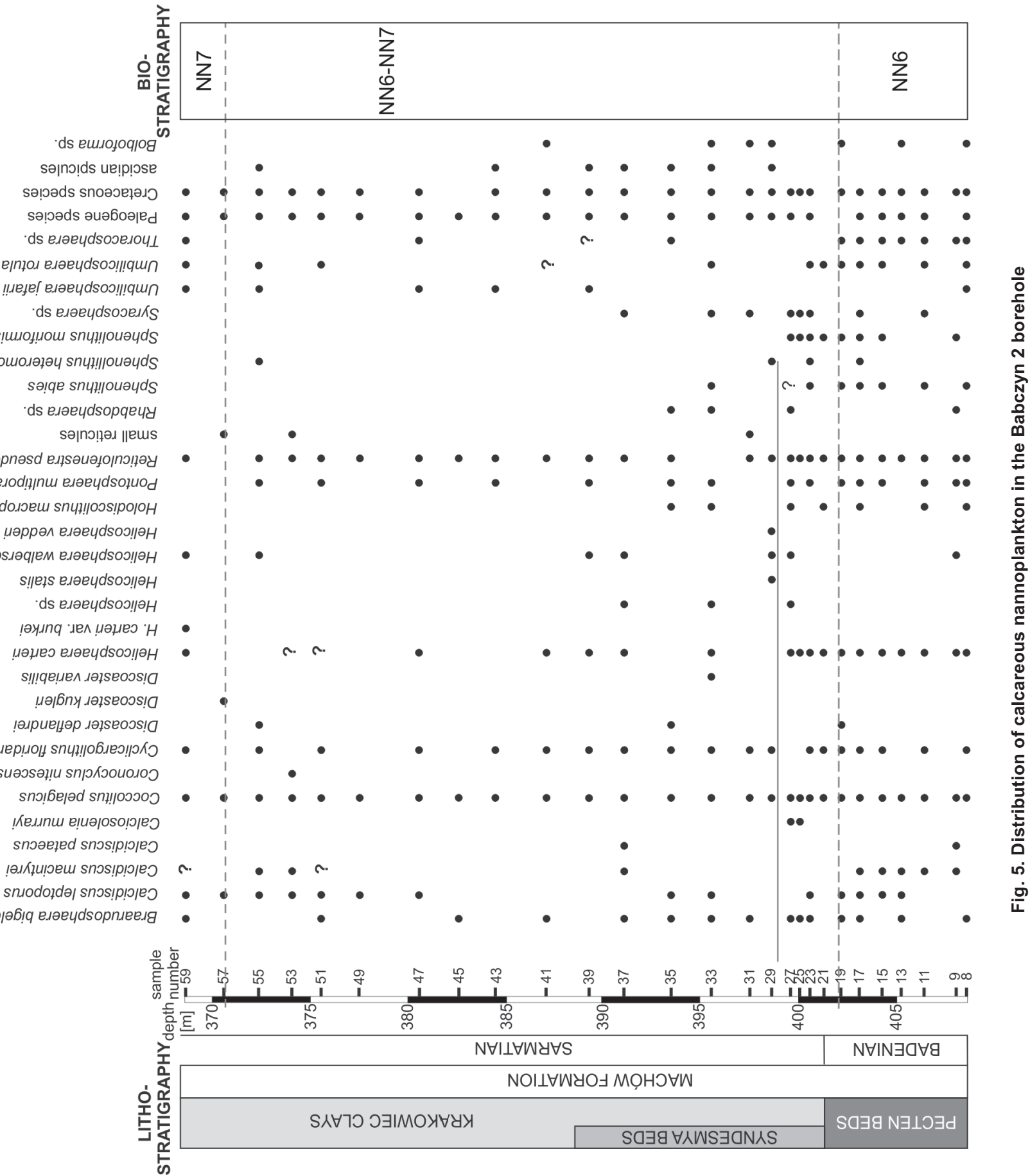


R. psudoumbilicus forms occur very rarely. The occurrence of reworked forms is characteristic for sample 31 (depth of $397.5 \mathrm{~m}$ ) which contains common pyritized Bolboforma spp. and very rare Syracosphaera sp., Braarudosphaera bigelowii and small-sized Reticulofenestra. The common occurrence of $B$. bigelowii (and coccospheres of this species) and Rhabdosphaera sp. is noted in sample 33 (depth of $395.5 \mathrm{~m}$ ), and $C$. pelagicus and Sphenolithus abies are rare. In the next interval (389.5-393.5 m; samples 35, 37, 39) R. pseudoumbilius and $C$. pelagicus are the main component of the assemblage and in samples 35 and 37 Reticulofenestra pseudoumbilcus prevails significantly over $C$. pelagicus. In sample 37 common occurrence of small Helicosphaera forms (probabby these are badly preserved $H$. walbersdorfensis) and single Calcidiscus pataecus occur as well as frequent reworked Cretaceous forms. The next interval 384.0-387.0 m (samples 41, 43) is characterized by the high frequency of Coccolithus pelagicus and reworked Paleogene forms. In sample 45 (depth of $352.5 \mathrm{~m}$ ) B. bigelowii and R. pseudoumbilicus are the main component of the assemblage, and in the interval of 377.0-380.5 m (samples 47 and 49) calcareous nannoplankton assemblage consists mainy of $R$. pseudoumbilicus and C. pelagicus (R. pseudoumbilicus prevailing in sample 49) and single individuals of Calcidiscus leptoporus were observed. In samples 51, 53, 55, 57, 59 (interval of 368.0-375.0 m) Cd. leptoporus occurs in each sample with rare to common frequency. Except for samples 51 and 59, in which C. pelagicus is common, in the other samples from this interval $R$. pseudoumbilicus and $C$. pelagicus occur rarely or these are only trace amounts. In sample 51 well-preserved, frequent $B$. bigelowii forms were observed. Discoaster kugleri was identified at a depth of $371.0 \mathrm{~m}$ (sample 57). At a depth of $368.0 \mathrm{~m}$ (sample 59 ) besides $C$. pelagicus and $C d$. leptoporus the common occurrence of calcareous dinoflagellata Thoracosphaera species was noted.

\section{CIESZANÓW 1}

$$
\text { (FIG. 6) }
$$

The depth interval of $378.0-385.9 \mathrm{~m}$ (samples 3 to 15) is characterized by the common occurrence of Cretaceous forms and common fragments of coccoliths (mechanically disintegrated). In sample 3, Reticulofenestra pseudoumbilicus occurs abundantly, and in the other samples of this interval it is rare or common. Coccolithus pelagicus, Sphenolithus moriformis, Sph. abies, Umbilicosphaera rotula, and Cyclicargolithus floridanus (very rare) occur also in the assemblage.

In the interval of $375.5-378.0 \mathrm{~m}$ (samples 15-19) Helicosphaera carteri occur commonly.

The interval comprising samples 17 to 35 (depth of $367.8-377.8 \mathrm{~m}$ ) is characterized by the occurrence of Coccolithus pelagicus, Reticulofenestra pseudoumbilicus, Braarudosphaera bigelowii, and $H$. carteri. Other species such as Cyclicargolithus floridanus, Syracosphaera spp., Umbilicosphaera rotula, and Thoracosphaera spp. occur very rarely. As in the underlying interval, taxa reworked from Cretaceous (mainly) and Paleogene and fragments of coccoliths occur frequently. In samples 27 and 29 fragments of Bolboforma spp. and diatom frustules were noted. The calcareous nannoplankton assemblage in samples 31 and 33 is characterized by higher species diversity although the abundance is still small (except of some species).

In the next interval (depth of 359.2-367.8 m; samples 35-47) R. pseudoumbilicus occurs in the all investigated samples with frequency from very rare to abundant. C. pelagicus occurs rarely or even these are only traces. Species such as
B. bigelowii, H. carteri, Calcidiscus sp., small-sized Helicosphaera sp., H. macroporus, small-sized Reticulofenestra, Rhabdosphaera spp. forms are distributed with low frequency (as single individuals mainly) and irregularly. In sample 37 Calcidiscus pataecus appears in the profile. Reworked Cretaceous and Paleogene species, coccospheres of undetectable species, Thoracosphaera sp., and ascidian spicules also occur.

The samples 49 to 55 from the last interval $(350.0-358.0 \mathrm{~m})$ are very impoverished.

The main component of the assemblage at a depth of $358.0 \mathrm{~m}$ is C. pelagicus. In samples 53 and $55 R$. pseudoumbilicus dominates. Other species such as B. bigelowii, $C d$. leptoporus occur rarely or very rarely and not in the all samples from this interval.

\section{INTERPRETATION}

\section{FORAMINIFERS}

Analysis of the distribution of foraminifers in both studied borehole sections enabled us to distinguish the following zones: Neobulimina longa Assemblage Zone, Hanzawaia crassiseptata Assemblage Zone, Elphidium angulatum Partial Range Zone, Anomalinoides dividens Interval Zone, Cycloforina karreri ovata Partial Range Zone, Varidentella sarmatica Interval Zone and Elphidium hauerinum Abundance Zone. Except for the Elphidium angulatum Partial Range Zone, proposed in this study, all others were previously established by Łuczkowska (1964) as assemblage zones. However, this type of biozone in many cases does give not precise information about the location of zonal boundaries.

Neobulimina longa Assemblage Zone - the body of strata containing Neobulimina longa, Bulimina elongata, and Lobatula lobatula. Common components of foraminiferal assemblages are Bulimina subulata, Bolivina plicatella, Uvigerina brunnensis, Elphidium angulatum, Haynesina depressula, Sigmoilinita tenuis, Astrononion perfossum and the planktonic Globigerina bulloides. Agglutinated benthic forms as well as Hanzawaia crassiseptata are lacking. This zone is recognized in the Babczyn 2 borehole in the lower part of the succession, at 404.3-409.1 m depth, between the top of the Krzyżanowice Formation deposits and the base of the Hanzawaia crassiseptata Zone; in the Cieszanów 1 borehole the zone is documented at 374.55-383.25 m depth.

Hanzawaia crassiseptata Assemblage Zone - the body of strata containing Hanzawaia crassiseptata, Sphaeroidina bulloides, and Hansenisca soldanii. Beside these species, common components of foraminiferal assemblages of the zone include $H$. boueana, Bulimina spp., Uvigerina spp., Angulogerina angulosa, Heterolepa dutemplei, Melonis pompilioides, the agglutinated species Siphotextularia inopinata, S. concava, Spirorutilus carinatus and abundant planktonic species Globigerina bulloides and Velapertina indigena. The upper boundary of the zone coincides with the sudden disappearance of foraminiferal species preferring normal marine conditions; only a few species of a relatively wide-range of tolerance to environmental changes survived, e.g. elphidiids and hauerinids.

The zone is underlain by the Neobulimina longa Assemblage Zone and overlain by the Elphidium angulatum Partial Range Zone. It occurs at a depth of 399.4-404.3 $\mathrm{m}$ in the Babczyn 2 borehole and a depth of 368.85-374.55 $\mathrm{m}$ in the Cieszanów 1 borehole, and its thickness is $4.9 \mathrm{~m}$ and $5.7 \mathrm{~m}$, accordingly. 
smuоoqlog sə|nэ!̣ds ue!̣!̣se

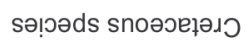
sə!̣әds әиәбоәе -ds ejaeydsooejoy1 eाmұd esәeydsoग!!!qun !neje! exəeydsoग!!!qun 'ds esәeydsojexks s!miо!!

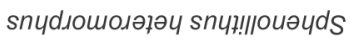
sə!qe sny?!/ouəyds ds eıəeydsopqeyl sә|пวฺฺฎ ॥еus

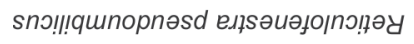
esod!łnu esәeydsoluod snıodosoeu sny!!

!!чग!|ाем еләецdsоэ!|ән !!!|әs eләечdsoग!|ән s!suәرор s!|lełs eләецdsoग!|ән е!рәщиәци еләецdsоэ!|ән dds eıәeydsoग!ləH !әуция 'גем цәнцео 'H بәرео еләец dsoэ!|ән !әрие|эәр ләңsеоэs!

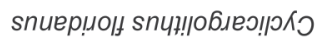

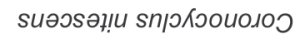
sno!6ejəd sn!! 00000

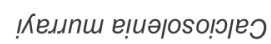

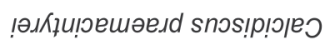
snoәejed snos!p!jleo

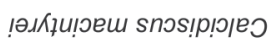
sniodoldəl snos!p!oleo !!мо|ә6!q eıәечdsopnıевя
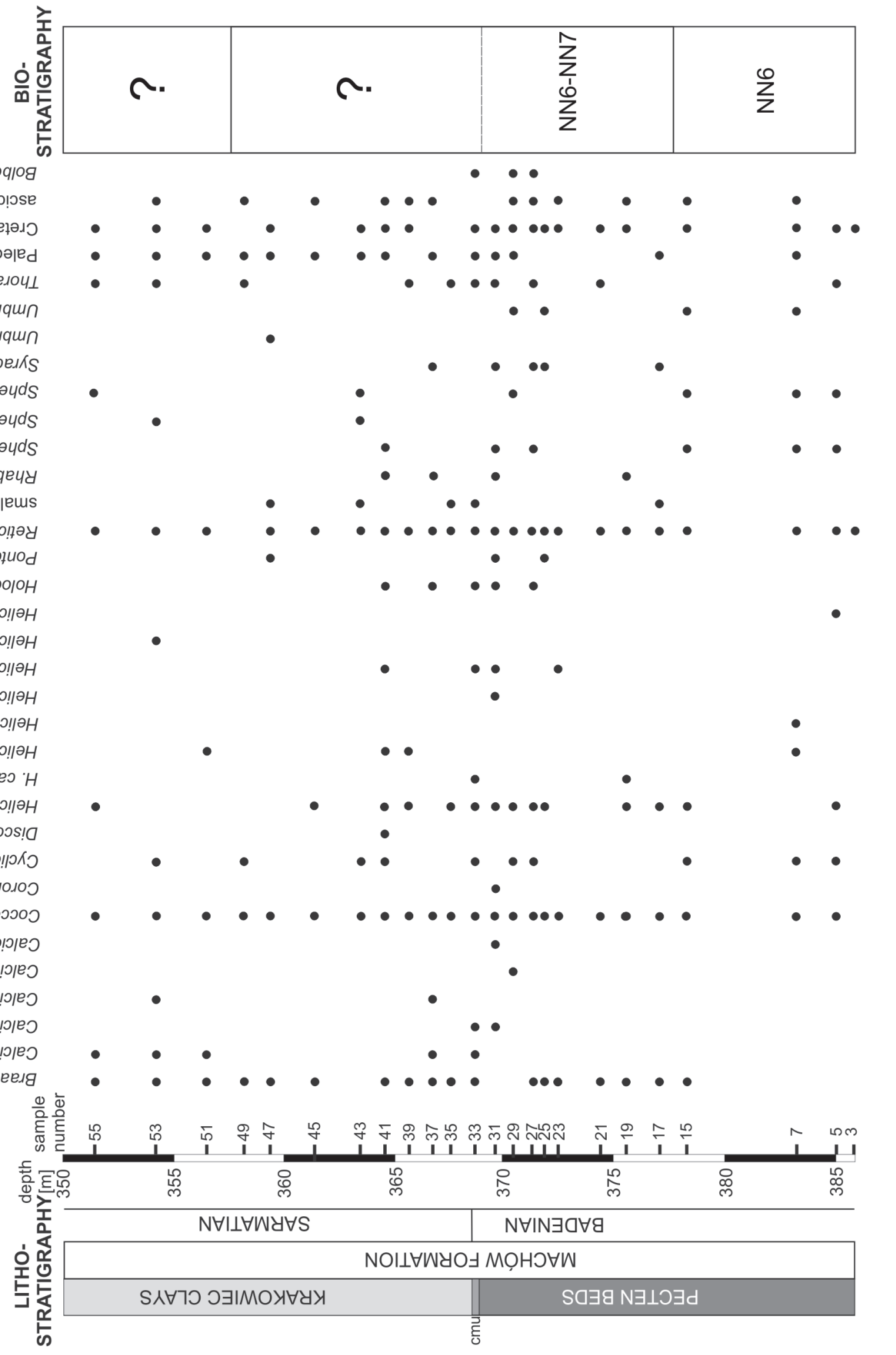

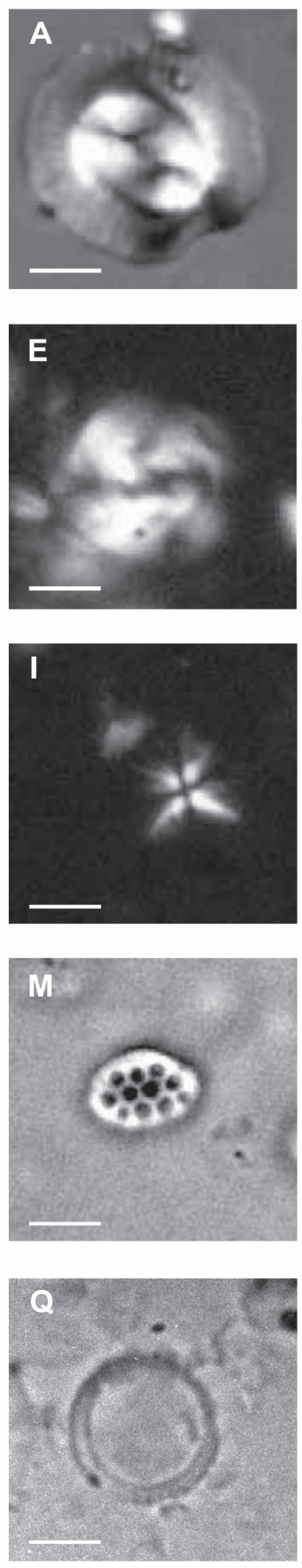
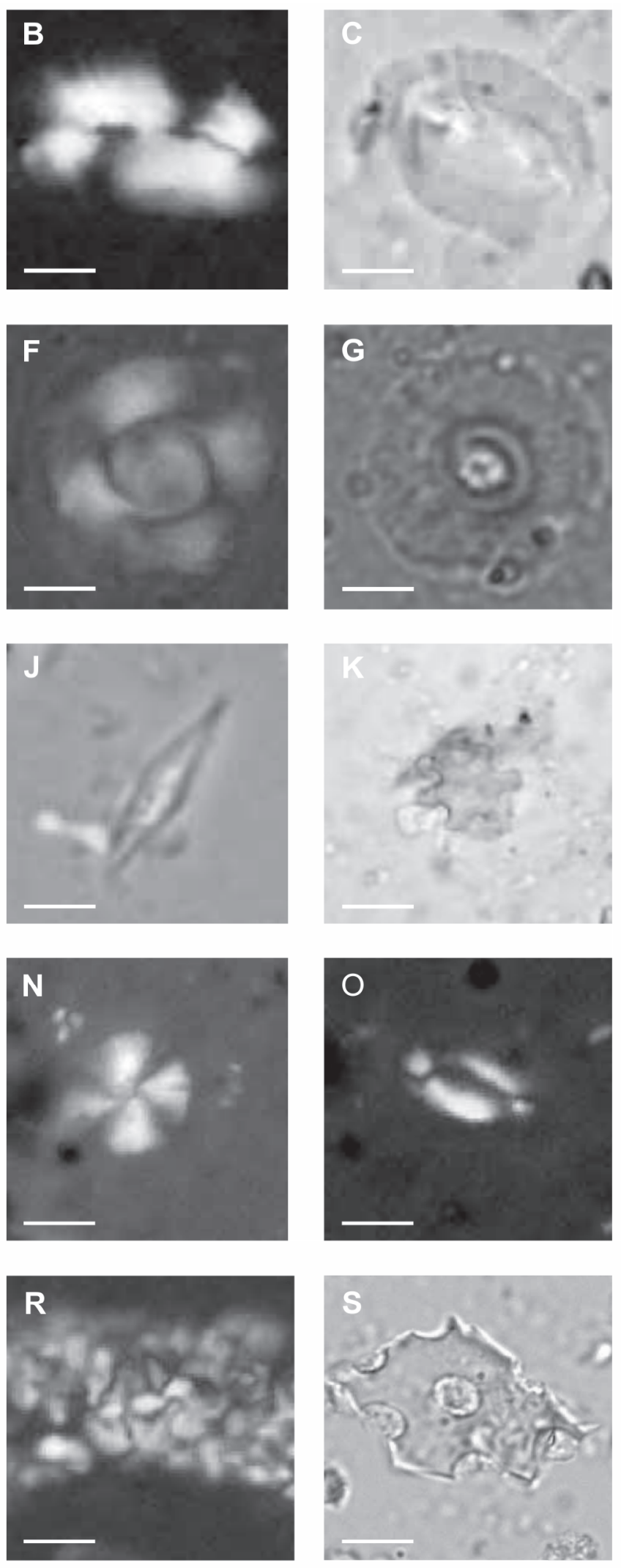
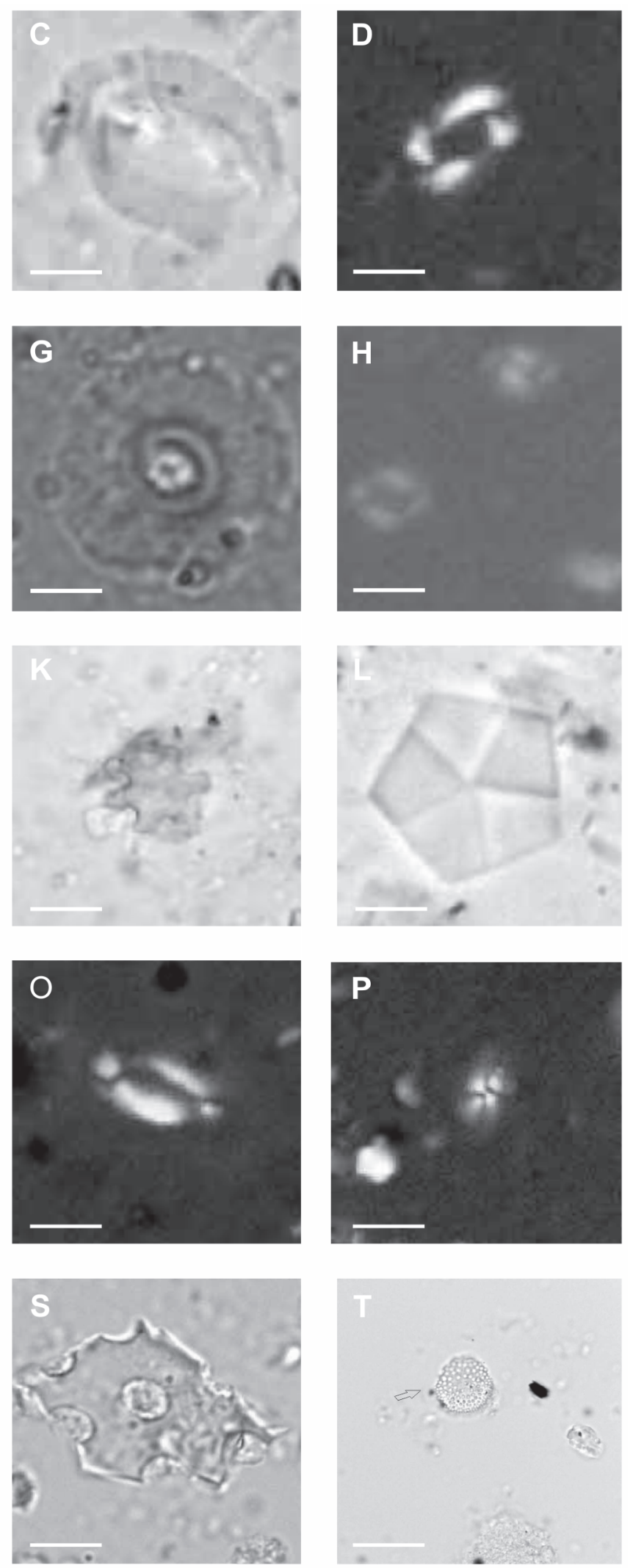

Fig. 7. Calcareous nannoplankton in the Babczyn 2 borehole

A - Coccolithus pelagicus (Wallich) Schiller, sample 8; B - Helicosphaera carteri (Wallich) Kamptner (CN), sample8; C - Helicosphaera carteri (Wallich) Kamptner (NL), sample 8; D - Reticulofenestra pseudoumbilicus Gartner (CN), sample 8; E - Cyclicargolithus floridanus (Roth et Hay) Bukry (CN), sample 29; F - Calcidiscus macintyrei (Bukry and Bramlette) Loeblich and Tappan (CN), sample 53; G Calcidiscus macintyrei (Bukry and Bramlette) Loeblich and Tappan (NL), sample 53; H - Reticulofenestra spp. - small forms (CN), sample 53; I - Sphenolithus abies Deflandre (CN), sample 8; J - Calciosolenia murrayi Gran (NL), sample 25; K - Discoaster kugleri Martini and Bramlette (NL), sample 57; L - Braarudosphaera bigelowii (Gran and Braarud) Deflandre (NL), sample 25; M - Holodiscolithus macroporus (Deflandre) Roth (NL), sample 8; N - Calcidiscus leptoporus ((Murray and Blackman) Loeblich and Tappan (CN), sample 53; 0 Helicosphaera walbersdorfensis Müller (CN), sample 59; P - Syracosphaera sp. (CN), sample 25; Q - Coronocyclus nitescens (Kamptner) Bramlette and Wilcoxon) (NL), sample 53; R - Thoracosphaera sp. - fragment (CN), sample 59; $\mathbf{S}$ - fragment of Bolboforma sp., sample 8; T - Diatomae sp.(?) (NL), sample 8; scale bar is $5 \mu \mathrm{m}$ 

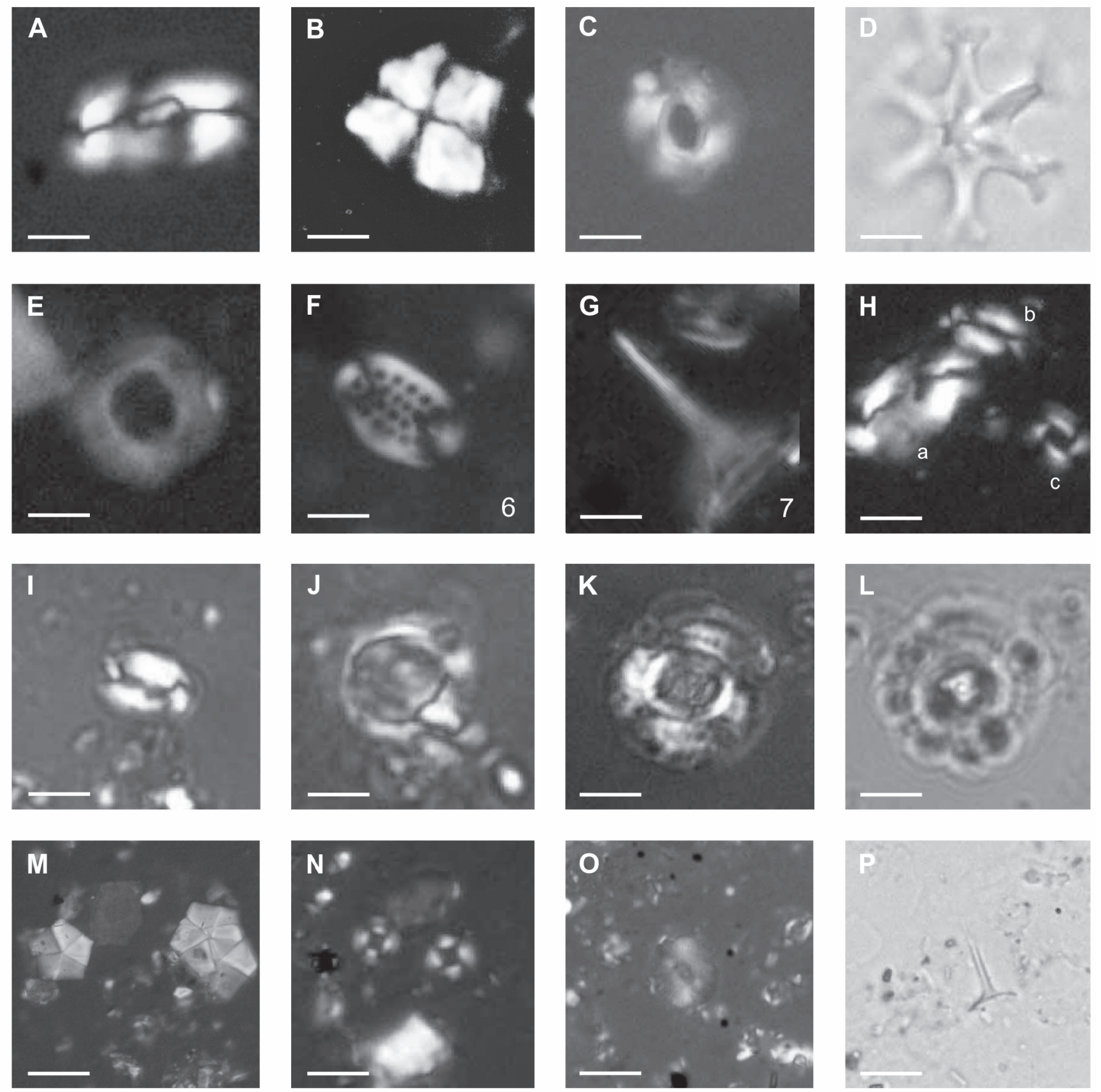

Fig. 8. Calcareous nannoplankton in the Cieszanów 1 borehole

A - Helicosphaera intermedia Martini (CN), sample 7; B - Sphenolithus moriformis (Brönnimann and Stradner) Bramlette and Wilcoxon (CN), sample 5; C - Calcidiscus premacintyrei Theodoridis, sample 29; D - Discoaster variabilis Martini et Bramlette (NL), sample 41; E Hayella challengeri (Müller) Theodoridis (CN), sample 41; F - Pontosphaera multipora (Kamptner) Roth (CN), sample 41; G Rhabdosphaera sicca (Stradner) Fuchs and Stradner (CN), sample 41; H - Helicosphaera carteri (Wallich) Kamptner [a], Helicosphaera walbersdorfensis Müller [b], Reticulofenestra pseudoumbilicus Gartner [c] (CN), sample 41; I- Helicosphaera stalis Theodoridis (CN), sample 31; J - Umbilicosphaera rotula (Kamptner) Varol (CN), sample 15; K - Calcidiscus macintyrei (Bukry and Bramlette) Loeblich and Tappan (CN), sample 33; L - Calcidiscus macintyrei (Bukry and Bramlette) Loeblich and Tappan (NL), sample33; M - Braarudosphaera bigelowii (Gran and Braarud) Deflandre (CN), sample 15; N - Umbilicosphaera jafarii Müller (CN), sample 47; 0 - Calcidiscus pataecus (Gartner) de Kaenel and Villa (CN), sample 53; P - Rhabdosphaera procera Martini (CN), sample 15; scale bar is $5 \mu \mathrm{m}$ 
Elphidium angulatum Partial Range Zone - the body of strata with Elphidium angulatum from the highest occurrence of Hanzawaia crassiseptata to the lowest occurrence of Anomalinoides dividens. The lower boundary of the zone corresponds with the level of disappearance of almost all foraminiferal species from the Hanzawaia crassiseptata zone. Common components of depauperate foraminiferal assemblages of the Elphidium angulatum PRZone, beside the zonal marker, are Porosononion martkobi, Cycloforina predkarpatica, and Quinqueloculina akneriana.

The zone is underlain by the Hanzawaia crassiseptata Assemblage Zone and overlain by the Anomalinoides dividens Interval Zone. It occurs at a depth of 395.6-399.4 $\mathrm{m}$ in the Babczyn 2 borehole and a depth of $365.75-368.85 \mathrm{~m}$ in the Cieszanów 1 borehole, and its thickness is $3.8 \mathrm{~m}$ and $3.1 \mathrm{~m}$, respectively.

Anomalinoides dividens Interval Zone - the body of strata from the lowest occurrence of Anomalinoides dividens to the lowest occurrence of Cycloforina karreri ovata. Łuczkowska (1964) defined this zone as an assemblage zone with a mass occurrence of $A$. dividens along with elphidiids and hauerinids in its upper part. According to Łuczkowska (1964, 1985) the assemblage with Anomalinoides dividens and some other Sarmatian species appeared abruptly above the level of extinction of foraminifers from the Hanzawaia crassiseptata Zone reflecting shallowing and a decrease in salinity. Ths study documented that the Anomalinoides dividens bioevent took place some time after the extinction of Badenian foraminifers because is separated by interval with depauparate assemblages composed of a few species of elphidiids and hauerinids of the Elphidum angulatum PR Zone. This means that the base of Anomalinoides dividens zone considered as an indicator of the Badenian/Sarmatian boundary is not coeval with the upper boundary of the Hanzawaia crassiseptata zone. Filipescu (2004) and Krezsek and Filipescu (2005) interpreted a wide geographical distribution of Anomalinoides dividens event in the Paratethyan area as reflecting the transgression initiated around the Badenian/Sarmatian boundary and suggested a pseudo-planktonic mode of life for Anomalinoides dividens (Filipescu, 2004).

The zone is underlain by the Elphidium angulatum Partial Range Zone and overlain by the Cycloforina karreri ovata Interval Zone. It occurs at a depth of 393.5-395.6 $\mathrm{m}$ in the Babczyn 2 borehole and a depth of 364.20-365.75 $\mathrm{m}$ in the Cieszanów 1 borehole, and its thickness is $2.1 \mathrm{~m}$ and $1.55 \mathrm{~m}$, accordingly.

Cycloforina karreri ovata Interval Zone - the body of strata from the lowest occurrence of Cycloforina karreri ovata to the lowest occurrence of Varidentella sarmatica, containing Cycloforina karreri ovata, Varidentella reussi, and Elphidium echinum.

The zone is underlain by the Anomalinoides dividens Interval Zone and overlain by the Varidentella sarmatica Interval Zone. It occurs at a depth of 380.6-393.5 $\mathrm{m}$ in the Babczyn 2 borehole and a depth of 354.25-364.20 m in the Cieszanów 1 borehole, and its thickness is $12.9 \mathrm{~m}$ and $9.95 \mathrm{~m}$, respectively.

Varidentella sarmatica Interval Zone - the body of strata between the lowest occurrence of Varidentella sarmatica and a consistent occurrence of Elphidium hauerinum.

The zone is underlain by the Cycloforina karreri ovata Interval Zone and overlain by the Elphidium hauerinum Abundance Zone in the Babczyn 2 borehole (in the Cieszanów 1 borehole the top of the zone is the top of section studied). It occurs at a depth of 370.4-380.6 $\mathrm{m}$ in the Babczyn 2 borehole and a depth of 350.0-354.25 $\mathrm{m}$ in the Cieszanów 1 borehole, and its thickness is $10.2 \mathrm{~m}$ and $>4.25 \mathrm{~m}$, accordingly.
Elphidium hauerinum Abundance Zone - the body of strata with a common and consistent occurrence of Elphidium hauerinum; the upper boundary of the zone is delimited by the top of the section measured (depth $368.4 \mathrm{~m}$ ), and the lower boundary, at a depth of $370.4 \mathrm{~m}$, is the Varidentella sarmatica Interval Zone. The thickness of the zone is $>2 \mathrm{~m}$.

\section{CALCAREOUS NANNOPLANKTON}

Based on our analyses of the upper Badenian-lower Sarmatian strata in the Babczyn 2 and Cieszanów 1 boreholes the following zones were distinguished: NN6 (Discoaster exilis Zone), undivided NN6-NN7 (Discoaster exilis-Discoaster kugleri zones) and NN7 (Discoaster kugleri Zone).

The lower part of the Babczyn 2 borehole was assigned into the upper part of the NN6 Zone based on the occurrence of Caldiscus leptoporus, Cd. macintyrei, Helicosphaera carteri, Reticulofenestra pseudoumbilicus, Sphenolithus abies, Umbilicosphaera rotula, $\mathrm{Cd}$. pataecus and Holodiscolithus macroporus. The lower boundary of the NN6 Zone is defined by Martini (1971) by the last occurrence of Sphenolithus heteromorphus, and the upper one by the first occurrence of Discoaster kugleri and/or the last occurrence of Cyclicargolithus floridanus. According to Martini (1971), the top part of the NN6 zone is characterized by the low frequency of Cy. floridanus, whereas Reticulofenestra pseudoumbilicus increases in numbers. In samples studied the frequency of $C y$. floridanus is low (only single forms were found in a slide, or it is absent). It occurs irregularly - not in every sample. The last occurrence of this long-ranging species varies with latitude and should be used carefully for long-distance correlation. In midand high latitudes, this species continued to the Late Miocene. Therefore, it was difficult or even imposible to distinguish between autochthonous and redeposited specimens. In the all investigated samples Reticulofenestra pseudoumbilicus prevails in abundance over Cy. floridanus which according to Galović (2019) could already indicate a Sarmatian age. Typical for the NN6 Zone are bigger specimens of Reticulofenestra pseudoumbilius (Fornaciari and Rio, 1996). Helicosphaera walbersdorfensis, another stratigraphically important species, in the Central Paratethys occurs in the NN5-NN7 zones, whereas in the Eastern Paratethys till the NN9 Zone (Galović and Young, 2012). In the investigated part of the Babczyn 2 section $H$. walbersdorfensis occurs only in a one sample (sample 9). In the lower part of the Pecten beds Calcidiscus pataecus was noted. According to Mărunteanu (1999) the occurrence of this form suggests the Late Badenian NN6c Subzone. In the Romanian part of the Paratethys the first occurrence of this species is mentioned at the end of Badenian but its abundant appearance marks the beginning of the Sarmatian (Galović, 2017). In Austria the first occurrence of Cd. pataecus represents the early Sarmatian (Schütz et al., 2007). The occurrence of Holodiscolithus macroporus (frequent in the lowermost part of the section Babczyn 2) suggests an oligotrophic deeper nearshore marine environment (Galović, 2017). The composition of the identified assemblage resembles the assemblage from the Pecten beds described by Gaździcka (1994) from the Tarnobrzeg area.

In the Cieszanów 1 borehole its lowermost studied part (interval 378.0-385.0 m; samples 5-15) representing the lower part of the Pecten beds, is characterized by the occurrence of Sphenolithus abies, S. moriformis and rare Umbilicosphaera rotula which suggest more open marine environmental conditions. This interval could be assigned to the upper Badenian NN6 Zone. The calcareous nannoplankton assemblage of the 
Pecten beds from Cieszanów 1 borehole is poorer in comparison with the assemblage form Babczyn 2 borehole.

The part of the Babczyn 2 section located above the lower part of the Pecten beds represents the undivided NN6-NN7 Zone. According to Cicha et al. (1998), the extent of the NN6 zone (upper Badenian-lower Sarmatian) does not allow to mark the Badenian/Sarmatian boundary based solely on the calcareous nannoplankton, and the two zones (NN6 and NN7) were combined into one undivided zone (NN6-NN7; Andreyeva-Grigorovich and Savitskaya, 1996; AndreyevaGrigorovich et al., 1997, 2003, 2008). According to Young (1998), the NN6-NN7 interval is characterized by the low species diversity and taxa which occurred in the earlier assemblages are rare or disappear. Reticulofenestra pseudoumbilicus, Coccolithus pelagicus, Calcidiscus leptoporus, Discoaster exilis, Helicosphaera carteri, Umbilicosphaera species are characteristic for this interval. The usefulness of the first occurrence of Discoaster kugleri as a zonal marker is problematic. In badly preserved material it is difficult to distinguish $D$. kugleri from other similar, overgrown, destroyed discoasters. Discoaster species, including species described as $D$. kugleri, are never numerous in the Polish segment of Paratethys (Gaździcka, 1994; Wójcik and Jugowiec, 1998; AndreyevaGrigorovich et al., 2003; Garecka and Olszewska, 2011; Garecka in: Studencka et al., 2017). The single specimen of $D$. kugleri in the Pecten beds at Machów suggests, according to Gaździcka (1994), redeposition. According to Vass (1999) the extreme rarity of $D$. kugleri refers to conditions under which marine nannoflora could not thrive. The identification of discoasters is problematic or even difficult because of the ease with which they are damaged during transport and because of common calcite overgrowth (Peryt and Peryt, 1994; Báldi, 2006). Discoasters are typical for warm open oceanic environments of low tropical and subtropical areas. Among them are forms such as Discoaster deflandrei, $D$. exilis and $D$. variabilis which are more tolerant and occur in cooler waters (Chira and Mărunteanu, 1999). The scarce occurrence of discoaster species suggests not only cooler waters but also coastal environments (Oszczypko-Clowes et al., 2012). Their distribution is conditioned by palaeogeography. They are more common in the Mediterranean than in the more isolated Paratethys. The very rare occurrence of $D$. kugleri was mentioned by Mărunteanu (1999) from the lower part of Sipotel Formation of the Subcarpathian Inner Zone (Romania), which contains a poor calcareous nannoplankton assemblage of the NN7 Zone. The nannoassemblage with $D$. kugeri, Discoaster deflandrei, R. pseudoumbilicus, Triquetrorhabdulus rugosus, C. pelagicus, Cd. leptoporus, H. carteri was found in Romania (Dumitriu et al., 2017, 2020). The CNM10 (Discoaster kugleri Total Range Zone) of Backman et al. (2012), which corresponds to the lowermost part of Zone NN7 (Martini, 1971), is characterized by the occurrence of $D$. kugleri. The interval of common and continuous presence of $D$. kugleri has been observed in the tropical Pacific, mid-latitude northern and tropical Atlantic, and in the Mediterranean (Raffi et al., 1995; Backman and Rafii, 1997). According to Švábenicka (2002) epicontinental marine sediments contain smaller sized and less numerous specimens in comparison with sediments deposited under oceanic conditions. Martini (1977) also drew attention to the small size of some species while studying the Middle Miocene sediments of the Korytnica basin (Holy Cross Mts.). The high number of redeposited nannofossils, high number of damaged elements of coccoliths, scarce occurrence (or absence) of some species (i.e. Miocene index species), mainly poor preservation suggest a supply of terrigenous material into the basin and an unstable shallow-water environment (Garecka and Olszewska, 2011).
The studied interval in the Babczyn 2 borehole which was assigned to the NN6-NN7 zones is characterized by a low diversity calcareous nannoplankton assemblage, the absence of $D$. kugleri, and very rare (single occurrences in slides) of $C y$. floridanus. R. pseudoumbilicus and C. pelagicus are the important and main components of the nannoassociation. In the samples H. carteri, Calcidiscus leptoporus, Cd. macintyrei, Sphenolithus species, Syracosphaera sp., Rhabdosphaera sp., and Umbilicosphaera sp. also occur. The high number of redeposited nannofossils (Cretaceous and Paleogene), high number of damaged elements of coccoliths, scarce occurrence (or absence) of some species (i.e. Miocene index species) and mainly poor preservation characterize the samples from this interval. In addition to calcareous nannoplankton fragments of pyritized Bolboforma sp., Thoracosphaera sp., coccospheres of C. pelagicus, Reticulofenestra pseudoumbilicus, Braarudosphaera bigelowii and undistinguishable forms and ascidian spicules were identified. The spicules produced by ascidians can be found with calcareous nannoplankton species in the same samples (Young, 1998; Varol, 2006). According to Galović (2017) ascidian spicules (Perforocalcinella fusiformis) occur in the Sarmatian shallow near-shore regions of the Croatian Basin. They preferred high nutrient areas and mixomesohaline conditions during the early Sarmatian (Galović, 2014; Łukowiak et al., 2016). In investigated samples ascidian spicules are badly preserved and they cannot be identified to the species level. These are mainy damaged fragments only. Bolboforma sp. also occur in the Middle Miocene assemblage of the Carpathian Foredeep (Odrzywolska-Bieńkowa, 1976; Szczechura, 1997, 2000; Paruch-Kulczycka, 2003). These marine microfossils produced calcitic monocrystalline spheroidal tests with or without inner cysts and with various types of ornamentation. Due to the preservation state of observed fragments it was impossible to relate them to the previously-described species or Bolboforma zones. Thoracosphaera species are the common constituent of the marine nannoplankton (Inouye and Pienaar, 1983) and they are placed in calcareous nannoplankton because of their size. These are solution resistant forms which occur abundantly in marine surface oligo- and eutrophic waters (Karwath et al., 2000; Gussone et al., 2010). Their increasing abundance indicates, according to Agnini et al. (2007), stressed environmental conditions in the photic zone. In the investigated samples the presence of thoracospheres is not related to the specific coccolith species or environmental conditions.

In the Syndesmya beds of the Tarnobrzeg area Gaździcka (1994) observed an increase in numbers of $B$. bigelowii and Thoracosphaera spp. In the Babczyn 2 borehole the species $B$. bigelowii is present whereas Thoracosphaera spp. do not occur.

The interval of 368.5-377.0 $\mathrm{m}$ (samples 17-33) in the Cieszanów 1 borehole represents the undivided NN6-NN7 Zone. Reticulofenestra pseudoumbilica, Coccolithus pelagicus, Helicosphaera carteri and Braarudosphaera bigelowii are the main component of the assemblage. The other forms, such as Cyclicargolithus floridanus, Holodiscolithus macroporus, Pontosphaera multipora, Umbilicosphaera rotula, Syracosphaera sp., Sphenolithus moriformis, Sph. abies, Rhabdosphaera sp. and Thoracosphaera species occur very rarely or are absent. Ascidian spicules and calcareous dinoflagellata occur in this interval. A huge amount of species reworked from the Cretaceous and sporadically Paleogene and fragments of damaged coccolits were observed. D. kugleri is absent. Cy. floridanus occurs as single specimens in only a few samples.

Based on the occurrence of Discoaster kugleri the uppermost part of the Babczyn 2 section was assigned into the NN7 
Zone. The assemblage also contains Calcidiscus leptoporus and Coccolithus pelagicus. In the Cieszanów 1 borehole the interval of 351.0-368.5 m can represent the Sarmatian NN7 Zone. The assemblage is more impoverished in comparison to the underlying assemblages. $R$. pseudoumbilicus and $C$. pelagicus are the main components, but there are samples in which R. pseudoumbilicus dominates over C. pelagicus and vice versa, and intervals in which these species do not occur or occur rarely (what otherwise was observed in the whole section). According to Beaufort et al. (1990) fluctuations in abundance between these two species could be explained by, or has relationship with Milankovich periodicities. $H$. carteri occurs as individuals only and $C$. floridanus occurs only as individuals in two samples in this interval. In the uppermost part of this interval Cd. leptoporus appears. According to Palcu et al. (2015) a shift in dominance of nannofossil assemblages occurs in the Badenian/Sarmatian boundary interval. In the Cieszanów 1 borehole the decrease in abundance of $C$. pelagicus is observed in the interval of 351.0-368.5 m. R. pseudoumbilicus occurs more commonly owing to its opportunistic behaviour: as a more tolerant species, during times of environmental stress it is more successful than C. pelagicus.

\section{DISCUSSION}

Odrzywolska-Bieńkowa (1972b) in a short communication concluded that in the Babczyn borehole a 350 m thick complex of mudstones occurs that represents entirely the Protelphidium (= Porosononion) subgranosum zone. She reported rare Syndesmya sp. and Limnocardium sp. and common otolites, fish scales and vertebrae in the Babczyn borehole. She concluded that as Elphidium hauerinum is lacking, the Sarmatian strata in the Babczyn borehole are younger than previously recorded in other Polish areas. There are two Babczyn boreholes: 1 and 2, and regrettably, Odrzywolska-Bieńkowa (1972b) did not give its number, however, considering the borehole timing and coring it seems that the Babczyn 1 borehole was studied by her. The Babczyn 1 borehole (N50¹4'01.76", E2312'38.75') was stopped on 10th October 1958 at a depth of $388.4 \mathrm{~m}$, and it was fully cored (Pawłowska and Kubica, 1958). Subsequently, on the 20 th of December 1958, drilling of the Babczyn 2 borehole began and its coring started at a depth of $350 \mathrm{~m}$ (Pawłowska and Kubica, 1960). It can be assumed that in the Babczyn 2 borehole the uncored part of the section represents the Porosononion subgranosum zone, and the boundary with the underlying Elphidium hauerinum zone is located somewhere between the depths of 350 and $368.4 \mathrm{~m}$ (the latter being the top of the sampled section).

Śliwiński et al. (2012) assumed that the BSEE occurred within the transitional interval between the Pecten beds and Syndesmya beds, but at the same time they stressed the need for further studies. Czapowski (1984: fig. 2) placed the Badenian/Sarmatian boundary within the Syndesmya beds in the section of the southern margin of the Holy Cross Mts. Czapowski (1984) considered that the Pecten beds-Syndesmya beds boundary coincides with the boundary between the Cibicides crassiseptatus (= Hanzawaia crassiseptata) and Neobulimina longa zones. Czapowski (1994) later concluded that in the area south of Tarnobrzeg (north-central part of the Carpathian Foredeep) in the lower part of Syndesmya beds foraminifers Hanzawaia crassiseptata Łuczkowska was frequently found, which documents its late Badenian age, and higher in the section abundant Anomalinoides dividens Łuczkowska as well as Quinqueloculina sarmatica Karrer occurred, the index foraminifers for the lower
Sarmatian (Łuczkowska, 1964). In addition, as pointed out by Śliwiński et al. (2012), pectinids were recovered from deposits in the lower portion of the Syndesmya beds in the Gwoździec P10 core examined by Czapowski (1994: fig. 5), indicating they should therefore be grouped together with the Pecten beds and assigned a latest Badenian age (cf. Kowalewski, 1966; Osmólski, 1972; Rutkowski, 1976). However, the concept of the position of Badenian/Sarmatian boundary within the Syndesmya beds (Czapowski and Gąsiewicz, 1994) was then apparently not supported (Czapowski in: Piwocki et al., 1996). A different approach was proposed by Gąsiewicz et al. (2004) who proposed that chemostratigraphical boundary between the Badenian and Sarmatian is placed $>10 \mathrm{~m}$ above the biostratigraphical boundary. This difference was interpreted by them as due to the influence of ecological conditions eliminating the Badenian assemblages earlier than the distinctive change in geochemical record occurred.

Łuczkowska (1985) concluded that in the marly-clayey facies of the northern Carpathian Foredeep the lithological boundary between the Badenian and Sarmatian, clearly visible in borehole setions due to a distinct change in colour of the rock which is grey-green in typical Pecten beds of the upper Badenian and light grey in the "Krakowiec clays" of the lower Sarmatian, is in accordance with the lithological one. According to her (Łuczkowska, 1985), the upper Badenian assemblages typical of a normal saline, marine environment "abruptly disappear at the end of the Kosovian, showing no traces of regression or gradual deterioration. Above them, at a distance of a few centimetres within the drill core, there appear equally abruptly assemblages characteristic of shallow-water, near-shore conditions of decreased salinity, which indicates a complete change of environmental conditions. The assemblages contain abundant species typical of the Sarmatian, such as Anomalinoides dividens, Varidentella sarmatica, Articulina sarmatica, A. problema, Elphidium reginum, E. hauerinum, E. listeri".

The occurrence pattern of foraminiferal taxa in the Babczyn 2 and Cieszanów 1 boreholes (Figs. 2 and 3) strongly supports the observations and conclusions of Łuczkowska (1985) about the abrupt environmental change at the Badenian/Sarmatian boundary (cf. Czepiec, 1996). However, our observations do not support that the lithological boundary corresponds to the biostratigraphical boundary, at least when foraminifers are concerned. As shown in Figures 2 and 3, there are two potential options (which are discussed below) to assign the Badenian/ Sarmatian boundary based on the foraminiferal assemblages in both boreholes studied but neither of them follows the earlier designated one. In any case, in the Babczyn 2 borehole the Badenian/Sarmatian boundary occurs within the Syndesmya beds, and in the Cieszanów 1 borehole it occurs either at the base of the $35 \mathrm{~cm}$ thick unit of calcareous marls occurring at a depth 368.5-368.85 $\mathrm{m}$ above the Pecten beds or in the lower part of the Krakowiec clays, at a depth of $\sim 362.5 \mathrm{~m}$.

A consensus exists that at the Badenian-Sarmatian a major change in the benthic and planktonic foraminiferal assemblages occurred (e.g., Hudáčková et al., 2019).

Anomalinoides dividens is considered as an index taxon for the regional biostratigraphy of the Paratethyan area, and the Anomalinoides dividens Zone was introduced in order to trace the boundary between Badenian and Sarmatian deposits (e.g., Łuczkowska, 1964, 1967; Czepiec, 1996; Filipescu, 2004; Dumitriu et al., 2017). In the Babczyn 2 and Cieszanów 1 borehole sections Anomalinoides dividens appears, however, 3.1-3.8 $\mathrm{m}$ above the rapid environmental change expressed by the replacement of stenohaline by euryhaline foraminifers. Therefore, the Anomalinoides dividens zone is preceded by the Elphidium angulatum Zone, which is the lowermost Sarmatian 


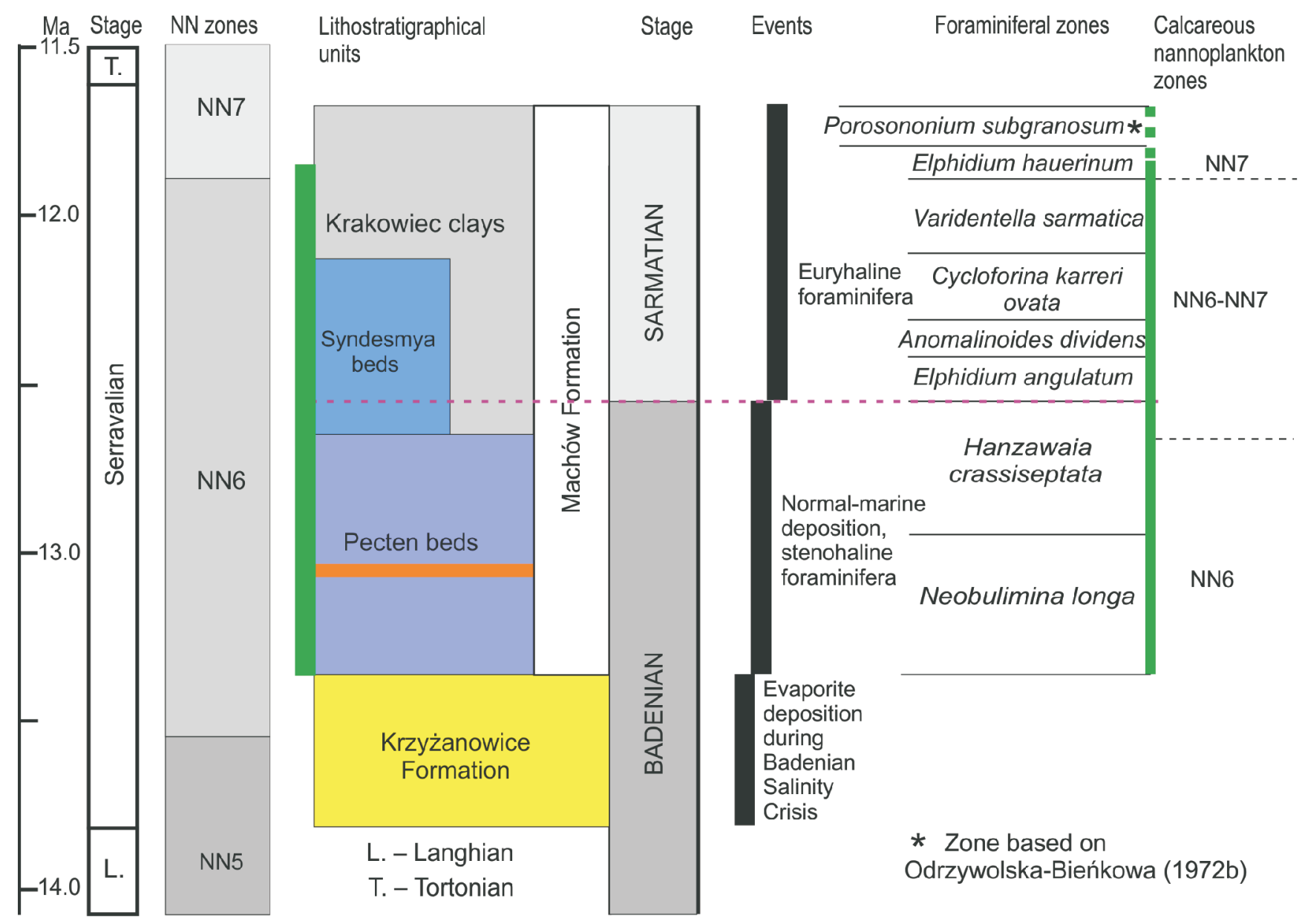

Fig. 9. Stratigraphic position of the Babczyn 2 section inferred from the present study and correlation of environmental history

International chronostratigraphic correlation and NN zones (Martini, 1971) after Hilgen et al. (2012), Central Paratethys stratigraphy after Sant et al. (2017), age and duration of the BSC after de Leeuw et al. (2018); orange bed within the Pecten beds is a rhyolite tuff of depositional age of $13.06 \pm 0.11 \mathrm{Ma}$ (Śliwiński et al., 2012)

biozone in the boreholes, and consequently the Badenian/ Sarmatian is placed several metres lower in the section compared to the option when it is assumed to be identical with the appearance of Anomalinoides dividens (Figs. 2, 3 and 9). Consequently, the Syndesmya beds in the Babczyn 2 borehole represent the upper part of the Hanzawaia crassiseptata Zone, Elphidium angulatum and Anomalinoides dividens zones and the lower part of the Cycloforina karreri ovata Zone.

Śliwiński et al. (2012) assigned the boundary between the Pecten and Syndesmya beds at the highest occurrence of well preserved and identifiable pectinid shells, $6.0 \mathrm{~m}$ above the tuff and maintained that the boundary interval between these beds marks the beginning of the deterioration of normal marine conditions within the basin. They further supposed that the disappearance of pectinids is more or less coincident with the appearance of the endemic Anomalinoides dividens Łuczkowska (Śliwiński et al., 2012). Our data clearly indicate that it was not the case. Consequently, the updated version of their Figure 2, presenting the regional Paratethyan Badenian-Sarmatian stratigraphy and events in the northern part of the Polish Carpathian Foredeep basin, is shown in Figure 9.

Previous studies of calcareous nannoplankton of the Pecten beds and the lower part of Krakowiec clays resulted in contradictory interpretations. Gaździecka (1994) concluded that the Pecten beds and the Syndesmya beds of the
Tarnobrzeg area, are younger than the NN7 Zone, and the recorded single occurrence of Discoaster kugleri in the Pecten beds which is diagnostic for the NN7 Zone was interpreted by her as due to redeposition. The occurrence of Discoaster calcaris and the absence of $D$. kugleri indicate the NN8 and even NN9 Zones (Gaździcka, 1994). This interpretation suggested unequivocally that the Badenian/Sarmatian boundary should be put below the Pecten beds. In turn, Jugowiec (in Garecka and Jugowiec, 1999) assigned the Pecten beds and the Krakowiec clays in the Kolbuszowa area (NW of Rzeszów) to the NN5 Zone. In the Sokołów-Smolarzyny area (north of Rzeszów) the lower part of the Machów Formation was assigned to the NN6 Zone and the upper part to the NN7 Zone (Oszczypko-Clowes in: Krzywiec et al., 2008; OszczypkoClowes et al., 2012). In the Sieniawa-Rudka area (between Rzeszów and Lubaczów) these sediments were assigned to the undivided NN6-NN7 zones although the composition of the calcareous nannoplankton assemblage may indicate the NN7 Zone (Lelek et al., 2016). Garecka and Olszewska (2011) concluded that the Krakowiec beds in the Księżpol 10, 11, 12, and Dzików 15 boreholes (NW of Lubaczów) are characterized by calcareous nannoplankton assemblages showing common reworked taxa and the damaged fragments of coccoliths (Garecka and Olszewska, 2011), and belong to the uppermost part of NN6 Zone and the NN7 Zone. The Krakowiec clays in 
the Przecław brickyard near Dębica (west of Rzeszów) based on the occurrence of $D$. kugleri were assigned into the NN7 Zone (the lower part) and the NN8 Zone based on the occurrence of Catinaster coalitus (the upper part) (Garecka in: Studencka et al., 2017).

The occurrence of Discoaster kugleri in sample 57 of the Babczyn 2 borehole indicates that this part of the section represents the NN7 Zone. The common occurrence of Calcidiscus leptoporus is characteristic for NN7 Zone (Chira et al., 2000). According to Bukry (1981), discoasters are the most solution-resistant group but they are damaged during transport. The absence or rare occurrence of them in the assemblage reflects not only the environmental conditions (trophy) but also temperature and a distance form the shore. The underlying interval (samples 23 till 55) represents the undivided NN6-NN7 zones. The character of the assemblage in this interval changes in comparison to the more normal marine assemblage typical of the Pecten beds. The decrease of individuals and species diversity is probably a result of fluctuation in salinity (the occurrence of Braarudosphaera bigelowii suggests a drop in salinity - Báldi-Beke, 1984; Chira, 2000; Bartol et al., 2008), more nearshore environment (as suggested by common occurrence of reworked and damaged coccoliths indicating an influx of terrigenous material, the absence of more open marine specimens such as Discoaster, Sphenolithus, Calcidiscus and Umbilicosphaera), and change in water chemistry and/or temperature. Discoaster kugleri is absent and Cyclicargolithus floridanus occurs very rare or even is absent in some samples. According to Galović (2019) Reticulofenestra pseudoumbilicus prevailing in abundance over Cyclicargolithus floridanus suggests a Sarmatian age. The usefulness of some other species (such as Cy. floridanus, Calcidiscus macintyrei, Coccolithus miopelagicus, Cd. premacintyrei) as alternative species which can mark the NN7 Zone is problematic because of their unspecified first or last occurrences, diachronous occurrence, and reworking.

In the Babczyn 2 borehole, the Syndesmya beds are characterized by the increase in abundance of Braarudosphaera bigelowii and very rare Helicosphaera, Calciosolenia murrayi, Syracosphaera and Rhabdosphaera. This assemblage suggest shallow, near shore environment. In sample 33 a frequent occurrence of $B$. bigelowii and coccospheres of this species were noted. These are mainly small pentaliths with sharp corners. According to Galović (2014), the Sarmatian is characterized by monofloral development of Reticulofenestra pseudoumbilicus and ascidian spicules, and in the Babczyn 2 borehole ascidian spicules appear in the interval which corresponds to the uppermost part of the Syndesmya beds. The Badenian/Sarmatian boundary according to calcareous nannoplankton observation can be placed above the Syndesmya beds (above sample 33). Calcidsicus leptoporus (and less common Cd. macintyrei) appear in the samples (often in the upper part of the section), and occasional Umbilico- sphaera jafarii occur. Common B. bigelowii suggests a fluctuation in water salinity in this interval.

In the case of the Cieszanów 1 borehole $D$. kugleri was not recorded. The interval $378.0-368.5 \mathrm{~m}$ is characterized by the occurrence of $C$. pelagicus, $R$. pseudoumbilicus, $H$. carteri and less common $B$. bigelowii. In the overlying interval, $H$. carteri occurs as individuals only and $\mathrm{Cy}$. floridanus does not occur (besides single occurrences in two samples). Very small $B$. bigelowii species, $\mathrm{Cd}$. leptoporus and mainly large forms of $R$. pseudoumbilicus dominating over $C$. pelagicus, which decrease in abundance at the depths shallower than $368.5 \mathrm{~m}$, may suggest the NN7 Zone rather than the undivided NN6-NN7 zones.

\section{CONCLUSIONS}

The study of two biostratigraphically important microfossil groups: foraminifers and calcareous nannoplankton in two borehole sections located in the marginal NE part of the Polish Carpathian Basin indicated that:

1. The upper Badenian strata represent the Neobulimina longa Assemblage Zone and Hanzawaia crassiseptata Assemblage Zone previously distinguished in the Central Paratethys. Those strata belong to the NN6 and undivided NN6-NN7 calcareous nannoplankton zones.

2. In the Sarmatian strata the following foraminiferal zones are distinguished: Elphidium angulatum Partial Range Zone, Anomalinoides dividens Interval Zone, Cycloforina karreri ovata Interval Zone, Varidentella sarmatica Interval Zone and Elphidium hauerinum Abundance Zone. Some zones have been previously defined in the Polish Carpathian Foredeep although their boundaries were not precisely defined until now. The Sarmatian strata studied belong to the undivided NN6-NN7 and NN7 zones.

3. The Badenian/Sarmatian boundary regarded as coeval with a major change in the benthic and planktonic foraminiferal assemblages, occurs within the Syndesmya beds in the Babczyn 2 borehole and slightly below the Krakowiec clays in the Cieszanów 1 borehole.

4. The Anomalinoides dividens Interval Zone starts, in the sections studied, 3.1 . to $3.8 \mathrm{~m}$ above the Badenian/ Sarmatian boundary as defined by the replacement of stenohaline by euryhaline foraminifers.

Acknowledgements. This study was financed by the National Science Centre, Poland, grant No. UMO-2017/27/B/ST $10 / 01129$ to the first author, and the pilot study was supported by the statutory funds of the PGI-NRI (project 61.2805.1702.00.0 to the second and third authors). S. Filipescu, K. Holcová, M.A. Kaminski and M. Oszczypko-Clowes offered very helpful comments to the earlier version of this paper.

\section{REFERENCES}

Agnini, C., Fornaciari, E., Raffi, I., Rio, D., Röhl, U., Westerhold, T., 2007. High-resolution nannofossil biochronology of middle Paleocene to early Eocene at ODP Site 1262: Implications for calcareous nannoplankton evolution. Marine Micropaleontology, 64: 215-248.
Alexandrowicz, S.W., Garlicki, A., Rutkowski, J., 1982. Podstawowe jednostki litostratygraficzne miocenu zapadliska przedkarpackiego (in Polish). Kwartalnik Geologiczny, 26 (2): $470-471$. 
Andreyeva-Grigorovich, A.S., Savitskaya, N.A., 1996. Organichni reshtki neogenovykh vykladiv - nannoplankton (in Ukrainian). Paleontologichnyi Zbirnik, 31: 20-23.

Andreyeva-Grigorovich, A.S., Gruzman, A.D., Trofimovich, N.A., Savitskaya, N.A., 1997. Biostratigraphy of the Miocene deposits of Carpathian Foredeep by foraminifera and nannoplankton. Annales Géologiques des Pays Helléniques, 37: 1-6.

Andreyeva-Grigorovich, A.S., Oszczypko, N., Savitskaya, N.A., Ślączka, A., Trofimovich, N.A., 2003. Correlation of late Badenian salts of the Wieliczka, Bochnia and Kalush areas (Polish and Ukrainian Carpathian Foredeep). Annales Societatis Geologorum Poloniae, 73: 67-89.

Andreyeva-Grigorovich, A.S., Oszczypko, N., Ślączka, A., Oszczypko-Clowes, M., Savitskaya, N.A., Trofimovich, N., 2008. New data on the stratigraphy of the folded Miocene Zone at the front of the Ukrainian Outer Carpathians. Acta Geologica Polonica, 58: 325-353.

Backman, J., Raffi, I., 1997. Calibration of Miocene nannofossil events to orbitally turned cyclostratigraphies from Ceara Rise. Proceedings of the Ocean Drilling Program, Scientific Results, 154: 83-98.

Backman, J., Raffi, I., Rio, D., Fornaciari, E., Pälike, H., 2012. Biozonation and biochronology of Miocene through Pleistocene calcareous nannofossils from low and middle latitudes. Newsletters on Stratigraphy, 47: 1-24.

Báldi, K., 2006. Mid-Tertiary stratigraphy and paleogeographic evolution of Hungary. Akadémiai Kiadó,Budapest.

Báldi-Beke, M., 1984. The nannoplankton of the Transdanubian Palaeogene formations. Geologica Hungarica, Series Palaeontologica, 43: 3-307.

Bartol, M., Pavšič, J., Dobnikar, M., Bernasconi, S.M., 2008. Unusual Braarudosphaera bigelowii and Micrantholithus vesper enrichment in the Early Miocene sediments from the Slovenian Corridor, a seaway linking the Central Paratethys and the Mediterranean. Palaeogeography Palaeoclimatology Palaeoecology, 267: 77-88.

Bąbel, M., 2005. Selenite-gypsum microbialite facies and sedimentary evolution of the Badenian evaporite basin of the northern Carpathian Foredeep. Acta Geologica Polonica, 55: 187-210.

Beaufort, L., Aubry, M.-P., 1990. Fluctuations in the composition of the Late Miocene calcareous nannofossils assemblages as a response to orbital forcing. Paleoceanography and Paleoclimatology, 5: 845-865.

Bielecka, M., 1974. Miocen okolic Zaklikowa, Zdziechowic i Wegglina (in Polish). In: Miocen przedgórza Karpat (eds. W. Krach, E. Łuczkowska and R. Ney): 43-54. Przewodnik wycieczki. VII Sympozjum na temat Paratetydy, Kraków.

Bukowski, K., 2011. Badenian saline sedimentation between Rybnik and Dębica based on geochemical, isotopic and radiometric research (in Polish with English summary). Dissertations Monographs, 236: 1-184.

Bukry, D., 1981. Cenozoic coccoliths from the Deep Sea Drilling Project. SEPM Special Publication, 32: 335-353.

Chira, C., 2000. Miocene calcareous nannoplankton and mollusks from Transylvania, Romania (in Romanian with English summary). Editura Carpatica.

Chira, C., Mărunteanu, M., 1999. Middle Miocene (Lower Badenian) calcareous nannofossils from the Mures passage way and Făget Basin, Romania. Acta Palaeontologica Romaniae, 5: 73-82.

Chira, C., Filipescu, S., Codrea, V., 2000. Palaeoclimatic evolution in the Miocene from the Transylvanian Depression reflected in the fossil record. Geological Society Special Publications, 181: 55-64.

Cicha, I., Rögl, F., Rupp, C., Čtyroká, J., 1998. Oligocene-Miocene foraminifera of the Central Paratethys. Kramer, Frankfurt am Main. Abhandlungen der Senckenbergischen Naturforschenden Gesellschaft, 549: 1-325.

Czapowski, G., 1984. Barrier rocks in Upper Miocene at southern margin of the Holy Cross Mts. (in Polish with English summary). Przegląd Geologiczny, 32: 185-194.
Czapowski, G., 1994. Sedimentation of Middle Miocene marine complex from the area near Tarnobrzeg (north-central part of the Carpathian Foredeep). Geological Quarterly, 38 (3): 577-592.

Czapowski, G., 2004. Wschodnia część zapadliska (in Polish). In: Budowa geologiczna Polski, tom I. Stratygrafia, część 3a Kenozoik Paleogen Neogen (eds. T.M. Peryt and M. Piwocki): 239-245.

Czapowski, G., Gąsiewicz, A., 1994. Preface. Geological Quarterly, 38 (3): 337-340.

Czepiec, I., 1996. Biostratigraphy and paleoenvironment of Sarmatian marginal zone of Poland (in Polish with English summary). Kwartalnik AGH, Geologia, 22: 309-338.

Czepiec, I., 1997. Sarmatian Foraminifera microfauna from the Carpathian Foredeep (in Polish with English summary). Kwartalnik AGH, Geologia, 23: 257-3005.

Czepiec, I., Kotarba, M.J., 1998. Paleoecology and organic matter in the Late Badenian and Early Sarmatian marine basin of the Polish part of the Carpathian Foredeep. Przegląd Geologiczny, 46: 732-736.

de Leeuw, A., Bukowski, K., Krijgsman, W., Kuiper, K.F., 2010. Age of the Badenian salinity crisis: Impact of Miocene climate variability on the circum-Mediterranean region. Geology, 38: 715-718.

de Leeuw, A., Tulburec, M., Kuiper, K.F., Melinte-Dobrinescu, M.C., Stoica, M., Krijgsman, W., 2018. New ${ }^{40} \mathrm{Ar} /{ }^{39} \mathrm{Ar}$, magnetostratigraphic and biostratigraphic constraints on the termination of the Badenian salinity crisis: Indications for tectonic improvement of basin interconnectivity in southern Europe. Global and Planetary Change, 169: 1-15.

de Leeuw, A., Vincent, S.J., Matoshko, A., Matoshko, A., Stoica, M., Nicoara, I., 2020. Late Miocene sediment delivery from the axial drainage system of the East Carpathian foreland basin to the Black Sea. Geology, 48: 761-765.

Dumitriu, S.D., Loghin, S., Dubicka, Z., Melinte-Dobrinescu, M.C., Paruch-Kulczycka, J., Ionesi, V., 2017. Foraminiferal, ostracod, and calcareous nannofossil biostratigraphy of the latest Badenian - Sarmatian interval (Middle Miocene, Paratethys) from Poland, Romania and the Republic of Moldova. Geologica Carpathica, 68: 419-444.

Dumitriu, S.D., Dubicka, Z., Loghin, S., Melinte-Dobrinescu, M.C., Paruch-Kulczycka, J., 2020. The evolution of the Carpathian Foredeep Basin during the latest Badenian and Sarmatian (Middle Miocene): inferences from micropalaeontological data. Geological Quarterly, 64 (4): 1004-1022.

Dziadzio, P., Maksym, A., Olszewska, B., 2006. Miocene deposition in the eastern part of the Carpathian Foredeep in Poland (in Polish with English summary). Przegląd Geologiczny, 54: 413-420.

Filipescu, S., 2004. Anomalinoides dividens bioevent at the Badenian/Sarmatian boundary - a response to paleogeographic and paleoenvironmental changes. Studia Universitatis Babeş-Bolyai, Geologia, 49: 21-26.

Filipescu, S., Tămaş, D.M., Bercea, R.-I., Tămaş, A., Bălc, R., Tabără, D., Bindiu-Haitonic, R., Silye, L., Auer, A., Krézsek, C., Schléder, Z., Săsăran, E., 2020. Biostratigraphic re-evaluation of the lower to middle Miocene succession in the Eastern Carpathians: a case study related to the oil fields of the Diapir Fold Zone, Romania. Geological Quarterly, 64 (3): 781-800.

Fornaciari, E., Rio, D., 1996. Latest Oligocene to early middle Miocene quantitative calcareous nannoplankton biostratigraphy in the Mediterranean region. Micropaleontology, 42: 1-36.

Galović, I., 2014. Palaeoecological changes through the Sarmatian beds on calcareous nannofossils of North Croatia, Central Paratethys. RMZ-Materials and Geoenvironment, 61: 177-182.

Galović, I., 2017. Sarmatian calcareous nannofossils assemblages in the SW Paratethyan marginal marine environments: Implications for palaeoceanography and the palaeoclimate. Progress in Oceanography, 156: 209-220.

Galović, I., 2019. Sarmatian (Late Serravallian - Early Tortonian) biostratigraphy: a case study in a marginal sea. Journal of Nannoplankton Research special - Abstracts Volume, 39. 
https://bib.irb.hr/datoteka/1022664.Galovic_2019 INA17_Abstract.pdf

Galović, I., Young, J., 2012. Revised taxonomy of some Middle Miocene calcareous nannofossils in the Paratethys. Micropaleontology, 58: 305-334.

Garecka, M., Jugowiec, M., 1999. Results of biostratigraphic study of Miocene in the Carpathian Foredeep based on calcareous nannoplankton (in Polish with English summary). Prace Państwowego Instytutu Geologicznego, 168: 29-41.

Garecka, M., Olszewska, B., 2011. Correlation of the Middle Miocene deposits in SE Poland and western Ukraine based on foraminifera and calcareous nannoplankton. Annales Societatis Geologorum Poloniae, 81: 309-330.

Gaździcka, E., 1994. Nannoplankton stratigraphy of the Miocene deposits in Tarnobrzeg area (northeastern part of the Carpathian Foredeep). Geological Quarterly, 38 (3): 553-570.

Gaździcka, E., 2015. Middle Miocene calcareous nannofossils and diatoms from the Busko and Kazimierza Wielka area (northern part of the Carpathian Foredeep) (in Polish with English summary). Biuletyn Państwowego Instytutu Geologicznego, 461: 153-177.

Gąsiewicz, A., Czapowski, G., Paruch-Kulczycka, J., 2004 Badenian-Sarmatian boundary in geochemical record in the Carpathian Foredeep area: stratigraphic implications (in Polish with English summary). Przegląd Geologiczny, 52: 413-420.

Gussone, N., Zonnenveld, K., Kuhnert, H., 2010. Minor element and $\mathrm{Ca}$ isotope composition of calcareous dinoflagellata cysts of cultured Thoracosphaera heimii. Earth and Planetary Science Letters, 289: 180-188.

Harzhauser, M., Piller, W.E., 2007. Benchmark data of a changing sea - palaeogeography, palaeobiogeography and events in the Central Paratethys during the Miocene. Palaeogeography Palaeoclimatology Palaeoecology, 253: 8-31.

Hilgen, F.J., Lourens, L.J., Van Dam, J.A., 2012. The Neogene Period. In: A Geologic Time Scale 2012 (eds. F.M. Gradstein, J.G. Ogg, M. Schmitz and G. Ogg): 923-978. Elsevier, Amsterdam.

Hudáčková, N., Ruman, A., Plašienková, I., Jamrich, M., Halásová, E., Kiss, P., Kováčová, M., Babejová-Kmecová, J., Kováč, M., 2019. Badenian/Sarmatian foraminifera shift in the Central Paratethys: two methods comparison - a morphogroup and species approach. In: Proceedings of the Geologica Carpathica 70 Conference, Smolenice Castle, Slovakia, October 9-11, 2019 (eds. I. Broska, M. Kohút and A. Tomašových): 144-145.

laccarino, S.M., Premoli Silva, I., Biolzi, M., Foresi, L.M., Lirer, F., Turco, E., Petrizzo, M.R., 2007. Practical Manual of Neogene Planktonic Foraminifera. In: International School on Planktonic Foraminifera (6th course) (eds. M. Biolzi et al.). Tipografia Pontefelicino, Perugia.

Inouye, I., Pienaar, R.N., 1983. Observations on the life cycle and microanatomy of Thoracosphaera heimii (Dinophyceae) with special reference to its systematic position. South African Journal of Botany, 2: 63-75.

Jasionowski, M., Peryt, T.M., 2004. Historia badań (in Polish). In: Budowa geologiczna Polski, tom I. Stratygrafia, część 3a Kenozoik Paleogen Neogen (eds. T.M. Peryt and M. Piwocki) 203-212.

Karwath, B., Janofske, D., Willems, H., 2000. Spatial distribution of the calcareous dinoflagellata Thoracosphaera heimii in the upper water column of the tropical and equatorial Atlantic. International Journal of Earth Sciences, 88: 668-679.

Kasprzyk, A., 1993. Lithofacies and sedimentation of the Badenian (middle Miocene) gypsum in the northern part of the Carpathian Foredeep, southern Poland. Annales Societatis Geologorum Poloniae, 63: 33-84.

Kasprzyk, A., 1995. Correlation of sulphate deposits of the Carpathian Foredeep at the boundary of Poland and Ukraine. Geological Quarterly, 39 (1): 95-108.

Kasprzyk, A., 2005. Diagenetic alteration of Badenian sulphate deposits in the Carpathian Foredeep Basin, southern Poland: Processes and their succession. Geological Quarterly, 49 (3): 305-316.
Kirchner, Z., 1956a. Próba korelacji mikrofaunistycznej poziomów miocenu Mielca i Pilzna (in Polish). Przegląd Geologiczny, 4: $10-13$.

Kirchner, Z., 1956b. Miocene stratigraphy of the Central Carpathian foreland based on microfaunal studies (in Polish with English summary). Acta Geologica Polonica, 6: 421-450.

Kováč, M., Márton, E., Oszczypko, N., Vojtko, R., Hók, J., Králiková, S., Plašienka, D., Klučiar, T., Hudáčková, N., Oszczypko-Clowes, M., 2017. Neogene palaeogeography and basin evolution of the Western Carpathians, Northern Pannonian domain and adjoining areas. Global and Planetary Change, 155: 133-154.

Kowalewski, K., 1957. Tertiaire de la Pologne méridionale, part 1 (in Polish with French summary). Biuletyn Instytutu Geologicznego, 119: 1-124.

Kowalewski, K., 1966. Tertiaire de la Pologne méridionale, part 4 (in Polish with French summary). Biuletyn Instytutu Geologicznego (without number): 1-143.

Krach, W., 1962. Esquisse de la stratigraphie du Miocène de la Pologne méridionale (in Polish with French summary). Annales de la Société Géologique de Pologne, 32: 527-557.

Krach, W., 1967. The Miocene of the vicinity of Grzybów near Staszów (in Polish with English summary). Acta Geologica Polonica, 17: 175-218.

Krach, W., 1981. The Pteropods in the Miocene of Poland and their stratigraphic significance (in Polish with English summary). Prace Geologiczne, 121: 116-134.

Krézsek, Cs., Filipescu, S., 2005. Middle to late Miocene sequence stratigraphy of the Transylvanian Basin (Romania). Tectonophysics, 410: 437-463.

Krzywiec, P., Wysocka, A., Oszczypko, N., Mastalerz, K., Papiernik, B., Wróbel, G., Oszczypko-Clowes, M., Aleksandrowski, P., Madej, K., Kijewska, S., 2008. Evolution of the Miocene deposits of the Carpathian Foredeep in the vicinity of Rzeszów (the Sokołów - Smolarzyny 3D seismic survey area) (in Polish with English summary). Przegląd Geologiczny, 56: 232-244.

Kubica, B., 1992. Lithofacial development of the Badenian chemical sediments in the northern part of the Carpathian Foredeep (in Polish with English summary). Prace Państwowego Instytutu Geologicznego, 133: 1-64.

Lelek, D., Oszczypko-Clowes, M., Oszczypko, N., 2016. Quantitative studies of the calcareous nannoplankton of Sarmatian deposits: case studies in the Sieniawa-Rudka area (Outer Carpathian Foredeep, Poland). Annales Societatis Geologorum Poloniae, 86: 29-57.

Łuczkowska, E., 1963. Foraminiferal zones in the Miocene, south of the Holy Cross Mts. Bulletin de l'Académie Polonaise des Sciences, Série des Sciences Géologiques et Géographiques, 10: 29-34.

Kuczkowska, E., 1964. The micropaleontological stratigraphy of the Miocene in the region of Tarnobrzeg-Chmielnik (in Polish with English summary). Prace Geologiczne, 20.

Łuczkowska, E., 1967. Paleoecology and micropalaeontological stratigraphy of the Miocene in the vicinity of Grzybów near Staszów (in Polish with English summary). Acta Geologica Polonica, 17: 219-249.

Łuczkowska, E., 1971. A new zone with Praeorbulina indigena (Foraminiferida, Globigerinidae) in the Upper Badenian (Tortonian s.s.) of central Paratethys. Annales de la Sociéte Géologique de Pologne, 40: 445-448.

Łuczkowska, E., 1972. Facjostratotyp sarmatu facji przybrzeżnej na Roztoczu Lubelskim (in Polish). Sprawozdania z Posiedzeń Komisji Naukowych PAN, Oddział w Krakowie, 16: 224-226.

kuczkowska, E., 1985. The Badenian-Sarmatian boundary in the light of foraminiferal research. Abstracts, VIII Congress RCMNS Budapest, 1985: 351-352. Budapest.

Łukowiak, M., Dumitriu, S.D., Ionesi, V., 2016. First fossil record of Early Sarmatian didemnid ascidian spicules (Tunicata) from Moldova. Geobios, 49: 201-209. 
Martini, E., 1971. Standard Tertiary and Quaternary calcareous nannoplankton zonation. Proceedings of the II Planktonic Conference, Roma (ed. A. Farinacci), 2: 739-785.

Martini, E., 1971. Calcareous nannoplankton from the Korytnica basin (Middle Miocene; Holy Cross Mountains, Poland). Acta Geologica Polonica, 27: 125-133.

Mărunteanu, M., 1999. Litho- and biostratigraphy (calcareous nannoplankton) of the Middle Miocene deposits from the Outer Moldavides. Geologica Carpathica, 50: 313-324.

Ney, R., 1969. The Miocene of the Southern Roztocze between Horyniec and Łówcza, and of the adjacent area of the Carpathian Foredeep (in Polish with English summary). Prace Geologiczne, 60.

Ney, R., Burzewski, W., Bachleda, T., Górecki, W., Jakóbczak, K., Słupczyński, K., 1974. Outline of paleogeography and evolution of lithology and facies of Neogene layers on the Carpathian Foredeep (in Polish with English summary). Prace Geologiczne, 82.

Odrzywolska-Bieńkowa, E., 1972a. Micropaleontological stratigraphy of the younger Tertiary in the borehole Dzwola, Roztocze area (in Polish with English summary). Kwartalnik Geologiczny, 16 (3): 669-675.

Odrzywolska-Bieńkowa, E., 1972b. Porównanie wybranych głębszych profile mikrofaunistycznych rejonu świętokrzyskiego i lubelskiego (in Polish). Sprawozdania z Posiedzeń Komisji Naukowych PAN, Kraków, 16: 493-494.

Odrzywolska-Bieńkowa, E., 1975. Micropaleontological stratigraphy of the Miocene of central part of the Carpathian Foredeep (in Polish with English summary). Przegląd Geologiczny, 23: 597-603.

Odrzywolska-Bieńkowa, E., 1976. On some species of the genus Bolboforma (Protozoa?) from the Miocene of Poland (in Polish with English summary). Kwartalnik Geologiczny, 20 (3): 551-558.

Olszewska, B., 1999. Biostratigraphy of Neogene in the Carpathian Foredeep in the light of new micropalaeontological data (in Polish with English summary). Prace Państwowego Instytutu Geologicznego, 168: 9-27.

Osmólski, T., 1972. The influence of the geological structure of marginal parts of the Działoszyce Trough on the metasomatosis of gypsum (in Polish with English summary). Biuletyn Instytutu Geologicznego, 260: 65-188.

Oszczypko, N., Krzywiec, P., Popadyuk, I., Peryt, T., 2006. Carpathian Foredeep Basin (Poland and Ukraine): its sedimentary, structural and geodynamic evolution. AAPG Memoir, 84: 293-350.

Oszczypko-Clowes, M., Lelek, D., Oszczypko, N., 2012. Sarmatian paleoecological environment of the Machów Formation based on the quantitative nannofossil analysis - a case study from the Sokołów area (Polish Carpathian Foredeep). Geologica Carpathica, 63: 267-294.

Palcu, D.V., Tulbure, M., Bartol, M., Kouwenhoven, T.J., Krijgsman, W., 2015. The Badenian-Sarmatian Extinction Event in the Carpathian foredeep basin of Romania: Paleogeographic changes in the Paratethys domain. Global and Planetary Change, 133: 346-358.

Paruch-Kulczycka, J., 2003. Stratigraphic value of Bolboforma (Protophyta, incertae sedis) of the Middle Miocene deposits from the Carpathian Foredeep and Roztocze Upland (Poland) (in Polish with English summary). Przegląd Geologiczny, 51: 1064-1068.

Pawłowska, K., Kubica, B., 1958. Karta otworu wiertniczego Babczyn-1 (in Polish; unpublished). National Geological Archive, CBDG No. 749076, Warszawa.

Pawłowska, K., Kubica, B., 1960. Karta otworu wiertniczego Babczyn-2 (in Polish; unpublished). National Geological Archive, CBDG No. 749044, Warszawa.

Pawłowska, K., Kubica, B., 1961. Karta otworu wiertniczego Cieszanów-1 (in Polish; unpublished). National Geological Archive, CBDG No. 892656, Warszawa.

Perch-Nielsen, K., 1985. Cenozoic calcareous nannofossils. In: Plankton Stratigraphy (ed. H.M. Bolli, J.B. Saunders and K.
Perch-Nielsen): 427-554. Cambridge University Press, Cambridge.

Peryt, D., 1987. Middle Miocene calcareous nannoplankton stratigraphy of the Roztocze Region (SE Poland). Bulletin of the Polish Academy of Sciences, Earth Sciences, 35: 391-401.

Peryt, D., Gedl, P., Peryt, T.M., 2020. Marine transgression(s) to evaporite basin: The case of middle Miocene (Badenian) gypsum in the Central Paratethys, SE Poland. Journal of Palaeogeography, 9: 16.

Peryt, T.M., 2006. The beginning, development and termination of the Middle Miocene Badenian salinity crisis in Central Paratethys. Sedimentary Geology, 188-189: 379-396.

Peryt, T.M., Kasprzyk, A., 1992. Carbonate-evaporite sedimentary transitions in the Badenian (middle Miocene) basin of southern Poland. Sedimentary Geology, 76: 257-271.

Peryt, T.M., Peryt, D., 1994. Badenian (Middle Miocene) Ratyn Limestone in western Ukraine and northern Moldavia: microfacies, calcareous nannoplankton and isotope geochemistry. Bulletin of the Polish Academy of Sciences, Earth Sciences, 42: 127-136.

Piwocki, M., Olszewska, B., Czapowski, G., 1996. Korelacja litostratygraficzna neogenu Polski z krajami sasiednimi (in Polish). In: Budowa geologiczna Polski, III. Atlas skamieniałości przewodnich i charakterystycznych, część 3a. Keneozoik Trzeciorzęd Neogen (eds. L. Malinowska and M. Piwocki): 517-529. Polska Agencja Ekologiczna, Warszawa.

Raffi, I., Rio, D., d'Atri, A., Fornaciari, E., Rocchetti, S., 1995. Quantitative distribution patterns and biomagnetostratigraphy of middle and late Miocene calcareous nannofossils from equatorial Indian and Pacific oceans (Leg 115, 130 and 138). Ocean Drilling Program, Scientific Results, 138: 479-502.

Rutkowski, J., 1976. Detrital Sarmatian deposits on the southern margin of the Holy Cross Mountains (southern Poland) (in Polish with English summary). Prace Geologiczne, 100.

Sant, K., Palcu, D., Mandic, O., Krijgsman, W., 2017. Changing seas in the early middle Miocene of Central Europe. Terra Nova, 29: 273-281.

Schütz, K., Harzhauser, M., Rögl, F., Ćorić, S., Galović, I., 2007. Foraminiferen und Phytoplankton aus dem unteren Sarmatium des südlichen Wiener Beckens (Petronell, Niederösterreich). Jahrbuch der Geologischen Bundesanstalt Wien, 147: 449-488.

Silye, L., Filipescu, S., 2016. Comment on "The Badenian-Sarmatian extinction event in the Carpathian foredeep basin of Romania: Paleogeographic changes in the Paratethys domain" (Palcu et al., 2015). Global and Planetary Change, 145: 17-19.

Simon, D., Palcu, D., Meijer, P., Krijgsman, W., 2019. The sensitivity of middle Miocene paleoenvironments to changing marine gateways in Central Europe. Geology, 47: 35-38.

Studencka, B., Bukowski, K., de Leeuw, A., Garecka, M., Pilarz, M., Witalis, P., 2017. New data on the age of the Machów Formation deposits filling the Fore-Carpathian basin in Poland: evidence from Przecław. 7th International Workshop Neogene of Central and South - Eastern Europe. Abstracts Book, May 28-31, 2017, Velika, Croatia: 65-66. http://bib.irb.hr/datoteka/ 902289.7NCSEE-Abstracts-book.pdf

Sulimski, A., 1956. Miliolidea Tortoniens et Sarmatiques de Suchowola (in Polish with French summary). Acta Palaeontologica Polonica, 1: 69-101.

Szczechura, J., 1982. Middle Miocene foraminiferal biochronology and ecology of SE Poland. Acta Palaeontologica Polonica, 27: 3-44.

Szczechura, J., 1997. Bolboforms (Protophyta, incerate sedis) from the Middle Miocene of Upper Silesia (Carpathian Foredeep, southwestern Poland). Bulletin of the Polish Academy of Sciences, Earth Sciences, 45: 133-144.

Szczechura, J., 2000. Age and evolution of depositional environments of the supra-evaporitic deposits in the northern, marginal part of the Carpathian Foredeep: micropalaeontological evidence. Geological Quarterly, 44 (1): 81-100.

Śliwiński, M., Bąbel, M., Nejbert, K., Olszewska-Nejbert, D., Gąsiewicz, A., Schreiber, B.C., Be-Nowitz, J.A., Layer P., 
2012. Badenian-Sarmatian chronostratigraphy in the Polish Carpathian Foredeep. Palaeogeography Palaeoclimatology Palaeoecology, 326-328: 12-29.

Švabenicka, L., 2002. Calcareous nannofossils of the upper Karpatian and Lower Badenian deposits in the Central Carpathian Foredeep. Geologica Carpathica, 53: 197-210.

Tóth, E., Görög, A., Lécuyer, C., Moissette, P., Balter, V., Monostori, V., 2010. Palaeoenvironmental reconstruction of the Sarmatian (Middle Miocene) Central Paratethys based on palaeontological and geochemical analyses of foraminifera, ostracods, gastropods and rodents. Geological Magazine, 147: 299-314.

Varol, O., 2006. Didemnid ascidian spicules from the Arabian Peninsula. Journal of Nannoplankton Research, 28: 35-55.

Vass, D., 1999. Numeric age of the Sarmatian boundaries (Suess, 1866). Slovak Geological Magazine, 5: 227-232.

Wójcik, A., Jugowiec, M., 1998. The youngest members of the folded Miocene in the Andrychów region (Southern Poland). Przegląd Geologiczny, 46: 763-770.

Young, J.R., 1998. Neogene. In: Calcareous Nannofossil Stratigraphy (ed. P.R. Bown): 225-265. Kluwer, Dordrecht. 